\title{
What do we know about who does and does not attend general health checks? Findings from a narrative scoping review
}

\author{
Ruth Dryden ${ }^{*}$, Brian Williams², Colin McCowan ${ }^{3}$ and Markus Themessl-Huber ${ }^{1}$
}

\begin{abstract}
Background: General and preventive health checks are a key feature of contemporary policies of anticipatory care. Ensuring high and equitable uptake of such general health checks is essential to ensuring health gain and preventing health inequalities. This literature review explores the socio-demographic, clinical and social cognitive characteristics of those who do and do not engage with general health checks or preventive health checks for cardiovascular disease.
\end{abstract}

Methods: An exploratory scoping study approach was employed. Databases searched included the British Nursing Index and Archive, Cumulative Index to Nursing and Allied Health Literature (CINAHL), Cochrane Database of Systematic Reviews (CDSR) and Database of Abstracts of Reviews of Effects (DARE), EMBASE, MEDLINE, PsycINFO and the Social Sciences Citation Index (SSCI). Titles and abstracts of 17463 papers were screened; 1171 papers were then independently assessed by two researchers. A review of full text was carried out by two of the authors resulting in 39 being included in the final review.

Results: Those least likely to attend health checks were men on low incomes, low socio-economic status, unemployed or less well educated. In general, attenders were older than non-attenders. An individual's marital status was found to affect attendance rates with non-attenders more likely to be single. In general, white individuals were more likely to engage with services than individuals from other ethnic backgrounds. Non-attenders had a greater proportion of cardiovascular risk factors than attenders, and smokers were less likely to attend than non-smokers. The relationship between health beliefs and health behaviours appeared complex. Non-attenders were shown to value health less strongly, have low self-efficacy, feel less in control of their health and be less likely to believe in the efficacy of health checks.

Conclusion: Routine health check-ups appear to be taken up inequitably, with gender, age, socio-demographic status and ethnicity all associated with differential service use. Furthermore, non-attenders appeared to have greater clinical need or risk factors suggesting that differential uptake may lead to sub-optimal health gain and contribute to inequalities via the inverse care law. Appropriate service redesign and interventions to encourage increased uptake among these groups is required.

Keywords: Health checks, Screening, Public health, Inequalities, Primary care

\footnotetext{
* Correspondence: r.dryden@dundee.ac.uk

${ }^{1}$ Social Dimensions of Health Institute, 11 Airlie Place, University of Dundee, Dundee, UK

Full list of author information is available at the end of the article
} 


\section{Background}

Anticipatory care [1] has increasingly been seen as a means by which the increasing demands of an aging population [2], growing numbers of people living with long term conditions, and persisting inequalities in health [3] may be addressed [4,5]. A key feature of such approaches are general and preventive health checks, defined as interventions which include a physical examination and/or an assessment of demographic and lifestyle risk factors which assess an individual's current health or predict their chance of developing illness in the future [6]. These may be carried out for primary and secondary preventive purposes, as part of annual routine health check-ups required among older age groups [7], or embedded opportunistically within routine clinical encounters [8].

Regular community based general health check-ups are important for the early identification of risk factors for conditions such as heart disease, diabetes and stroke [9], as evidenced in the recent introduction of Health Check within the United Kingdom (UK) National Health Service (NHS). The evidence base to support such health checks rests predominantly on the known efficacy of the individual screening components subsumed within them. For example, recent National Institute for Health and Clinical Excellence (NICE) guidance on the prevention of cardiovascular disease points to the known effectiveness of interventions within health checks in relation to risk assessment, smoking, and physical activity [10]. Such preventive health strategies may therefore also provide a cost effective way of dealing with the causes of ill health before they manifest into serious long-term conditions.

Despite the potential importance and benefit of such health checks, their uptake is known to be largely suboptimal [11]. For example, data illustrating the implementation of the recent NHS Health Check in the UK has shown uptake rates of around 50\% [12]. Furthermore, there is good reason to think that the pattern of uptake is likely to be differentially spread across socio-economic groupings and thus follow the inverse care law $[13,14]$ : those who have greatest to benefit from the services are least likely to engage with them. Differential uptake therefore has the potential to exacerbate health inequalities [14]. Consequently, knowledge of the socio-economic correlates of high and low uptake is important if current services are to be appropriately adapted in order to rectify such inequity.

Community based health-checks which aim to effectively and efficiently screen maximum proportions of eligible populations, are likely to be complex interventions consisting of numerous potential parameters: method of invite, location, timing, and nature (duration and content) of the screening process. Consequently, the development of new forms of health check should consider the theoretical and empirical basis to support maximal uptake $[15,16]$.

This exploratory scoping study aims to establish the nature and extent of current knowledge relating to the uptake and engagement with general health checks and preventative health checks for the risk factors of cardiovascular disease in particular, and thus contribute to the development of such a theoretical and empirical basis to informal future service development. In particular, it sought to address three fundamental questions:

1. What are the socio-demographic characteristics of those who do and do not engage with health checks?

2. What are their stated reasons for not attending health checks?

3. What are the clinical needs and risk factors of these non-attenders?

\section{Methods}

Establishing the state of knowledge with regard to a number of important but general questions requires a broad and inclusive review type rather than a highly focussed systematic review targeting a highly specified question around effectiveness. Scoping studies as defined by Arksey and O'Malley provide a structured but less restrictive alternative to the traditional systematic review of the literature [17]. They discuss four potential uses for a scoping study:

1. To examine the extent, range and nature of research activity

2. To determine the value of undertaking a full systematic review

3. To summarise and disseminate research findings

4. To identify research gaps in the existing literature" p6 [17].

This literature review followed an iterative scoping process which incorporated these objectives. The methodology was selected over the systematic review as its purpose was to explore the broad state of knowledge regarding attendance at general health checks rather than answer a clearly defined question. The breadth of potential studies and their heterogeneous nature meant that a scoping study with a narrative synthesis providing comprehensive representation of the evidence was more appropriate.

\section{Search strategy}

A search of bibliographic databases did not identify any existing systematic review which focused specifically on this topic, and a decision was made to develop an alternative search strategy designed specifically for the project. 


\section{Types of studies}

This review considered both quantitative and qualitative studies including, but not limited to: project evaluations, randomised controlled trials, cohort studies, experimental or quasi-experimental trials, uncontrolled trials, systematic reviews, meta-analyses and studies using evaluation methodology such as the theory of change. Inclusion and exclusion criteria were developed using the 'population, intervention, comparison and outcome' (PICO) acronym as a framework [18], and are detailed in Table 1. Differences in the delivery of health care systems may mean that findings from studies in underdeveloped countries may not be relevant to the context of this project. This resulted in the decision to restrict studies to developed countries. Similarly, studies where health insurance was not controlled for were excluded from the review. Findings were restricted to papers on general or preventive health checks for the risk factors of cardiovascular disease, as other disease specific screening programmes (for example breast screening) have their own intricacies with barriers which are better understood and findings which are not always transferable. Papers on geriatric annual health checks were excluded as these were less likely to be of a preventive nature due to the age group and focused more on functionality and ability to live independently than clinical or lifestyle risk factors. Some papers which were retrieved considered general health checks and disease specific screening within the same study. Therefore, papers were included if they contained both disease specific AND general heart health checks, but excluded if disease specific (other than heart/cardiovascular disease) screening was the main focus of the paper.

\section{Databases used}

The databases used for the review were the British Nursing Index and Archive, Cumulative Index to Nursing and Allied Health Literature (CINAHL), Cochrane Database of Systematic Reviews (CDSR) and Database of Abstracts of Reviews of Effects (DARE), EMBASE, MEDLINE, PsycINFO and the Social Science Citation Index (SSCI). A wide variety of databases were chosen to allow the complex concept of 'uptake of services' to be explored from a number of different disciplines. Searches were performed on each database individually to improve functionality and allow search terms and limits to be amended from the original template (Table 2) to meet each database's specifications. Specific database search strategies and terms are available from the authors. Given that predictors of uptake are likely to change over time as cultures, values and services change, a judgement was made to exclude older studies. A subjective judgment was made to include papers published from 1996 onwards.

\section{Selection process}

The search and review procedure was conducted systematically and is outlined below with the initials of the researchers involved alongside:

- Ran search in databases individually (RD)

- Removed duplicates within databases (RD)

- Removed duplicates between databases (RD)

- Papers screened for relevance by title (RD)

- Papers independently screened for relevance by abstract (RD and CM)

- Meeting to discuss agreement (RD, CM, BW)

Table 1 Inclusion \& exclusion criteria

\begin{tabular}{ll}
\hline Inclusion Criteria & Exclusion Criteria \\
\hline Population: & Population: \\
- Western/developed countries & • Children \\
- Hard to reach populations & Intervention: \\
- High risk groups & - Disease-specific health checks/screening (other than heart disease) \\
Intervention: & - Geriatric annual health checks \\
- General health checks & Control: \\
- Heart disease health checks & - Studies from the developing world \\
- General/Heart AND other disease-specific health check & Limits: \\
- Studies whose primary outcome was to increase uptake & - Non-English language papers \\
- Studies where uptake was documented (of the above interventions) & - Non-empirical opinion papers \\
Control: & - Papers published pre 1980 \\
- Control group not necessary & \\
Outcome: & \\
- Initial uptake of screening and/or & \\
\hline
\end{tabular}


Table 2 Search strategy

\begin{tabular}{|c|c|}
\hline \# & Search Term \\
\hline 1 & Health services for the aged \\
\hline 2 & (MH "Health Promotion") \\
\hline 3 & (MH "Preventive Health Services") \\
\hline 4 & (MH "Primary Prevention") \\
\hline 5 & "health check" \\
\hline 6 & "health examination" \\
\hline 7 & "health examinations" \\
\hline 8 & (MH "Family Practice") \\
\hline 9 & "general practice" \\
\hline 10 & "opportunistic" \\
\hline 11 & "health screening" \\
\hline 12 & $\mathrm{~S} 1$ or $\mathrm{S} 2$ or $\mathrm{S} 3$ or $\mathrm{S} 4$ or $\mathrm{S} 5$ or $\mathrm{S} 6$ or $\mathrm{S} 7$ or $\mathrm{S} 8$ or $\mathrm{S} 9$ or $\mathrm{S} 10$ or $\mathrm{S} 11$ \\
\hline 13 & (MH "Health Services Accessibility") \\
\hline 14 & (MH "Patient Acceptance of Health Care") \\
\hline 15 & (MH "Patient Dropouts") \\
\hline 16 & non-respon* \\
\hline 17 & (poor attend* or non-attend*) \\
\hline 18 & non-engage* \\
\hline 19 & non-particip* \\
\hline 20 & barrier* \\
\hline 21 & (dropout* or drop* out*) \\
\hline 22 & hard to reach \\
\hline 23 & inverse care law \\
\hline 24 & $\begin{array}{l}\mathrm{S} 13 \text { or } \mathrm{S} 14 \text { or } \mathrm{S} 15 \text { or } \mathrm{S} 16 \text { or } \mathrm{S} 17 \text { or } \mathrm{S} 18 \text { or } \mathrm{S} 19 \text { or } \mathrm{S} 20 \\
\text { or } \mathrm{S} 21 \text { or } \mathrm{S} 22 \text { or } \mathrm{S} 23\end{array}$ \\
\hline 25 & $\mathrm{~S} 12$ and S24 \\
\hline 26 & $\mathrm{TI}$ cancer or MW cancer or MJ cancer \\
\hline 27 & S25 NOT S26 \\
\hline 28 & S25 NOT S26 (English language) \\
\hline 29 & S25 NOT S26 (limited 1980-2010) \\
\hline
\end{tabular}

( $M H$ exact subject heading, $M J$ word in major subject heading, $M W$ word in subject heading, $T l$ title).

- Remaining papers screened using full text (RD and $\mathrm{BW})$

\section{Results}

A total of 17,463 studies were returned after searching the databases and performing electronic de-duplication within and between each database; the breakdown of papers by database is shown in Table 3 and the identification and exclusion of papers throughout the process is shown in Figure 1. A total of 39 papers were included in the final review (See Table 4). The findings of the literature review are presented below using a narrative synthesis reflecting the Economic and Social Research Council guidance [19].
What are the socio-demographic characteristics of those who do and do not engage with health checks?

Studies consistently indicate that males are less likely to engage with health checks or screening and to endorse periodic health examinations than females [20-28]. This difference in rates of non-attendance between males and females ranged from $8 \%$ to $19 \%$ in those invited for a health check at General Practice [21,23,24]. In community based drop-in sessions, women were more likely to self-present than males, with the proportion of attenders at least $60-65 \%$ female $[20,22]$. Additionally, $11 \%$ of men compared to $6 \%$ of women did not endorse periodic health examinations [28]. Two other studies found no difference in attendance rates by gender $[29,30]$.

In general, attenders at health checks are older than non-attenders [20-23,25,31-35], although some studies found no association between age and attendance [29,30,36-39]. In many cases the demographics of engagers were dependent on the targeting strategy of the intervention; for example where the service was only offered to a particular age group. Some of the included studies were targeted specifically at older adults while others were offered to an entire adult practice population. Although there was a tendency for attenders to be older than non-attenders, the heterogeneous nature of the study methodologies meant that it was difficult to define an optimum age for uptake. Indeed, the relationship between age and participation may not be linear. For example, participation in a health examination after completion of a health interview in the Netherlands followed a curve which rose with increasing age until 60 then declined significantly with any age above this [40].

Individuals were found to be less likely to attend if they had low socio-economic status [23,33,34,36,38,40,41]. Defining which socio-economic/demographic characteristics differentiate between attenders and non-attenders was complicated by the numerous ways social status was reported in the literature. Some studies discussed social class, employment status, occupational training and level

Table 3 Hits by database

\begin{tabular}{lccc}
\hline Database & $\begin{array}{c}\text { Number of } \\
\text { references }\end{array}$ & $\begin{array}{c}\text { Duplicates within } \\
\text { own database }\end{array}$ & $\begin{array}{c}\text { Distinct } \\
\text { references }\end{array}$ \\
\hline Medline & 8558 & 1 & 8557 \\
CINAHL & 3234 & 1 & 3233 \\
BNI & 148 & 0 & 148 \\
SSCI & 3902 & 1 & 3901 \\
PsycINFO & 1945 & 4 & 1941 \\
EMBASE & 2379 & 3 & 2376 \\
CDSR + DARE & 516 & 0 & 516 \\
Total & 20682 & 10 & 20672 \\
\hline
\end{tabular}




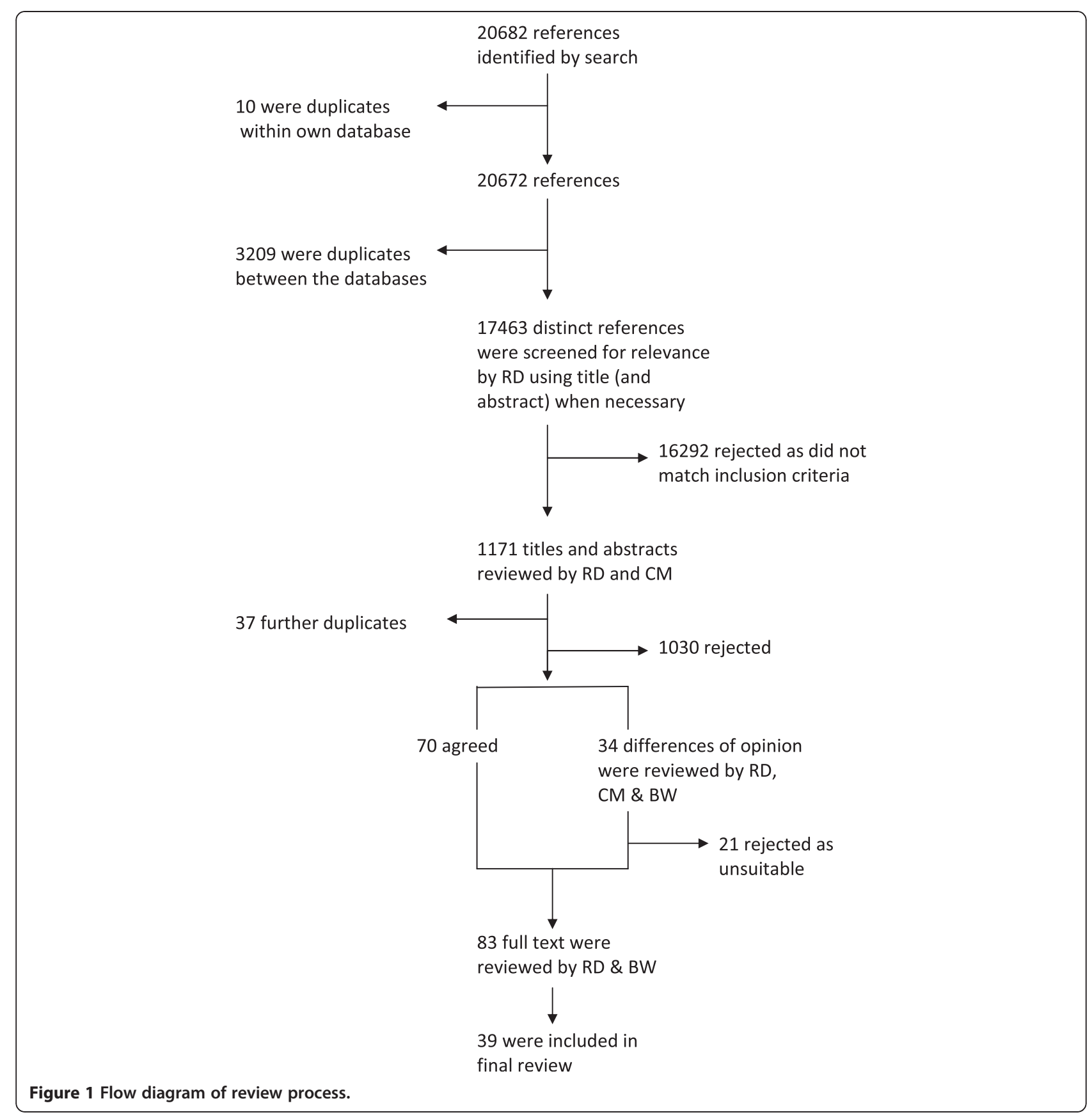

of education or years spent in education independently; whilst others used the terms interchangeably or as proxy measures for each other. In general lower uptake was associated with low incomes [21,30-32,42], being unemployed $[38,41,42]$ and lower educational attainment $[22,25,27,31-34,41]$. Although these terms may be closely related, one study found that each had an independent effect on the attendance rate [34].

An individual's marital status was found to affect attendance rates with non-attenders more likely to be single $[21,23,24,35,36,42]$. Studies suggested a possible interaction between marital status and gender in explaining uptake. For example, a number of studies reported that attendance at health checks was higher in males who were married or cohabiting, compared to single males $[21,24,35,42-44]$. A possible explanation was proposed in a qualitative study using focus groups with participants and non-participants in community health screenings, which found that the decision to attend a screening is often made by the partner, with this initiation behaviour prevalent across a number of socio-demographic factors [45]. 
Table 4 Summary of included studies

\begin{tabular}{|c|c|c|c|c|c|c|}
\hline $\begin{array}{l}\text { Reference } \\
\text { Number }\end{array}$ & $\begin{array}{l}\text { Primary } \\
\text { Author }\end{array}$ & Year & Title & Setting/Participants & Method & Key Findings \\
\hline \multirow[t]{6}{*}{20} & \multirow[t]{6}{*}{ Bletzer, K. V. } & \multirow[t]{6}{*}{1989} & \multirow{6}{*}{$\begin{array}{l}\text { Review of a health fair } \\
\text { screening program in Mid- } \\
\text { Michigan }\end{array}$} & America & \multirow{6}{*}{$\begin{array}{l}\text { Programme evaluation } \\
\text { Evaluation of } \\
\text { sociodemographic data on } \\
\text { attenders at health fairs } \\
\text { over seven years and } \\
\text { findings from a survey with } \\
\text { a sample of participants }\end{array}$} & - Women consistently \\
\hline & & & & \multirow[t]{5}{*}{$\begin{array}{l}\text { Health fair Open access } \\
15124 \text { participants }\end{array}$} & & $\begin{array}{l}\text { ratio of at least 3:2 every } \\
\text { year }\end{array}$ \\
\hline & & & & & & $\begin{array}{l}\text { - Older people were more } \\
\text { likely to present than } \\
\text { younger people, with half } \\
\text { of participants older than } \\
50\end{array}$ \\
\hline & & & & & & $\begin{array}{l}\text { - } 90 \% \text { of those surveyed } \\
\text { had consulted their GP } \\
\text { within the past two years }\end{array}$ \\
\hline & & & & & & $\begin{array}{l}\text { - The number of serious } \\
\text { problems identified was } \\
\text { low }\end{array}$ \\
\hline & & & & & & $\begin{array}{l}\text { - The main reason for } \\
\text { attendance was "curiosity } \\
\text { about health" }\end{array}$ \\
\hline 21 & Culica, D. & 2002 & $\begin{array}{l}\text { Medical checkups: Who } \\
\text { does not get them? }\end{array}$ & America & Telephone survey & $\begin{array}{l}\text { - Reduced likelihood of } \\
\text { having had health check in } \\
\text { the previous } 12 \text { months } \\
\text { was associated with being: } \\
25-44 \text { or over } 65 \text {, male, } \\
\text { unmarried, a smoker and in } \\
\text { those who perceived cost } \\
\text { barriers }\end{array}$ \\
\hline
\end{tabular}

- Check ups were more likely in people who earned over $\$ 75,000$, had health insurance, were physically active, had chronic disease and who rated their health as good, fair or poor rather than good or excellent

Sample of 3600 individuals $\quad$ Analysis of lowa 1996 Behavioral Risk Factor Surveillance System

22 Greenland, P. 2002 Attendance patterns and America characteristics of participants in public cholesterol screening cholesterol screening programme
Programme evaluation of

Cholesterol screening

Open access

10 supermarkets

8583 people were seen over 4 months
Comparison of participant demographics with local census data
- Participants more likely to be white (98.5\% v 96.7\%), older, female $(59.9 \% \mathrm{v}$ $51.6 \%)$ and better educated than the general population

- $22 \%$ had previous diagnosis of high cholesterol and came to confirm/monitor previous readings

- $79 \%$ came to the store specifically for screening

- Time was an important factor as weekend and weeknights attracted more men and younger people than weekday screenings

- Less than 5\% took time off work to participate 
Table 4 Summary of included studies (Continued)

\begin{tabular}{|c|c|c|c|c|c|c|}
\hline \multirow[t]{5}{*}{23} & \multirow[t]{5}{*}{ Waller, D. } & \multirow[t]{5}{*}{1990} & \multirow{5}{*}{$\begin{array}{l}\text { Health checks in general } \\
\text { practice: Another example } \\
\text { of inverse care? }\end{array}$} & \multirow[t]{2}{*}{ UK } & \multirow[t]{2}{*}{ Programme evaluation } & $\begin{array}{l}\text { - } 1458 \text { patients (65.9\%) } \\
\text { were offered screening }\end{array}$ \\
\hline & & & & & & $\begin{array}{l}\text { - Of those invited } 963 \\
(66 \%) \text { attended for a health } \\
\text { check }\end{array}$ \\
\hline & & & & $\begin{array}{l}\text { Attendance at General } \\
\text { Practice health checks } \\
\text { over }\end{array}$ & \multirow[t]{3}{*}{$\begin{array}{l}\text { Medical record audit and } \\
\text { postal questionnaire }\end{array}$} & $\begin{array}{l}\text { - Attenders were more } \\
\text { likely to be women, aged } \\
45 y \text { rs or older, married, } \\
\text { non-smokers and of higher } \\
\text { social class than the non- } \\
\text { responders to the } \\
\text { invitation }\end{array}$ \\
\hline & & & & $\begin{array}{l}2211 \text { men and women } \\
\text { aged } 35-64 \text { were in the } \\
\text { target age group }\end{array}$ & & $\begin{array}{l}\text { - Relative likelihood for } \\
\text { non-attendance was } 1.24 \\
\text { for smokers, } 1.20 \text { for the } \\
\text { overweight, } 1.16 \text { for heavy } \\
\text { drinkers, } 1.28 \text { for those with } \\
\text { a less healthy diet }\end{array}$ \\
\hline & & & & $\begin{array}{l}\text { Men were invited } \\
\text { opportunistically, women } \\
\text { were invited in the } \\
\text { context of cervical smear } \\
\text { tests }\end{array}$ & & $\begin{array}{l}\text { - Frequent GP consulters } \\
\text { were more likely to attend }\end{array}$ \\
\hline \multirow[t]{5}{*}{24} & \multirow[t]{5}{*}{ Jacobsen, B. K } & \multirow[t]{5}{*}{1992} & \multirow{5}{*}{$\begin{array}{l}\text { The Nordland Health Study } \\
\text { - Design of the Study, } \\
\text { Description of the } \\
\text { Population, Attendance } \\
\text { and Questionnaire } \\
\text { Response }\end{array}$} & Norway & $\begin{array}{l}\text { Quasiexperimental and } \\
\text { survey }\end{array}$ & $\begin{array}{l}\cdot 82 \% \text { attended the } \\
\text { screening }\end{array}$ \\
\hline & & & & Health screening & $\begin{array}{l}\text { Population screening and } \\
\text { questionnaire }\end{array}$ & $\begin{array}{l}\text { - } 78 \% \text { men and } 86 \% \\
\text { women attended }\end{array}$ \\
\hline & & & & & & $\begin{array}{l}\text { - Non-attenders tended to } \\
\text { be single }\end{array}$ \\
\hline & & & & Letter invitation & & $\begin{array}{l}\text { - } 84 \% \text { married men } \\
\text { attended screening } \\
\text { compared to } 65 \% \\
\text { divorced/single or } \\
\text { widowed men }\end{array}$ \\
\hline & & & & $\begin{array}{l}10497 \text { patients aged } 40-42 \\
\text { were invited }\end{array}$ & & $\begin{array}{l}\text { - } 88 \% \text { married women } \\
\text { attended compared to } 79 \% \\
\text { divorced/single or } \\
\text { widowed women }\end{array}$ \\
\hline \multirow[t]{9}{*}{25} & \multirow[t]{9}{*}{ Simpson, W.M. } & \multirow[t]{9}{*}{1997} & \multirow{9}{*}{$\begin{array}{l}\text { Screening for risk factors } \\
\text { for cardiovascular disease: } \\
\text { A psychological } \\
\text { perspective }\end{array}$} & UK & 1. Quasi-experimental & \multirow{2}{*}{$\begin{array}{l}\text { - Overall uptake } 62.4 \% ; 59 \% \\
\text { at further education } \\
\text { college, } 28 \% \text { at council } \\
\text { cleansing department, } 81 \% \\
\text { at greetings card factory. }\end{array}$} \\
\hline & & & & \multirow[t]{2}{*}{$\begin{array}{l}3 \text { studies (only two were } \\
\text { relevant to literature } \\
\text { review) }\end{array}$} & \multirow[t]{2}{*}{$\begin{array}{l}\text { Mobile screening } \\
\text { programme and } \\
\text { prospective questionnaire }\end{array}$} & \\
\hline & & & & & & $\begin{array}{l}\text { - In general attenders were } \\
\text { significantly older and } \\
\text { more likely to be female } \\
\text { than non-attenders }\end{array}$ \\
\hline & & & & \multirow{2}{*}{$\begin{array}{l}\text { 1. Worksite screening at } \\
\text { three workplaces: }\end{array}$} & 2. Longitudinal & \multirow{2}{*}{$\begin{array}{l}\text { - Attenders were more } \\
\text { likely to have had a } \\
\text { definite intention to attend, } \\
\text { and were more aware of } \\
\text { the availability of the } \\
\text { service }\end{array}$} \\
\hline & & & & & $\begin{array}{l}\text { Random allocation of } \\
\text { invitation type }\end{array}$ & \\
\hline & & & & Further education college & \multirow[t]{2}{*}{ Two questionnaires: } & \multirow{2}{*}{$\begin{array}{l}\text { - Non-attenders perceived } \\
\text { more barriers to } \\
\text { attendance and perceived } \\
\text { themselves to be at higher } \\
\text { risk of developing serious } \\
\text { diseases }\end{array}$} \\
\hline & & & & $\begin{array}{l}\text { Council Cleansing } \\
\text { department }\end{array}$ & & \\
\hline & & & & Greetings card factory & \multirow{2}{*}{$\begin{array}{l}\text { One week after screening } \\
\text { to assess intention to } \\
\text { change behaviour }\end{array}$} & \multirow{2}{*}{$\begin{array}{l}\text { - The lower uptake at the } \\
\text { council was attributed to } \\
\text { the higher ratio of male to }\end{array}$} \\
\hline & & & & Open access & & \\
\hline
\end{tabular}


2. Organisation of a screening programme

General Practice

Uptake by invitation type:

1. Opportunistic screening by GP

2. Invitation and fixed appointment to attend screening with practice nurse

3. Personal invite by GP to make appointment for screening clinic with practice nurse

210 male patients

\begin{tabular}{lll}
\hline 26 & Thomas, K. J. $1993 \begin{array}{l}\text { Case against targeting long } \\
\text { term non-attenders in } \\
\text { general practice for a } \\
\text { health check. }\end{array}$ & \\
& & \\
& & \\
& Mailed invitations \\
& Random sample of 679 \\
& patients who had not \\
& attended for 3 years and \\
& 379 patients who had \\
& attended within this time
\end{tabular}

Age 16-74
Three months after screening to measure behaviour change female employees, a lower education level and the youngest average age of all the workplaces

- Uptake varied by invitation type

- 100\% opportunistic patients, 54\% of those invited by letter and $29 \%$ personally invited attended the screening clinic

- The method of offering screening did not affect changes in behaviour but those who engaged opportunistically were more likely to intend to smoke less.

- Patients who engaged after being invited by letter or personally were more likely to eat less fat and take more exercise than those who engaged opportunistically

- Smokers were likely to attend than non-smokers

\section{Quasiexperimental Patient $\quad$ The median proportion of records were randomly 3 year non-attenders was sampled to assess attendance over a 3 year period. $23 \%$ in inner city practice compared to $9 \%$ in other practices}

-310/679 non-attenders were not contactable $v$ 320/379 attenders who were contactable. This was related to last recorded consultation

A sample of those who had attended in the past 3 years were invited for a health check and were invited to take part in a home interview two weeks before the health check

- Non-attenders were more likely to be female. Female non-attenders were more likely to be older than male non-attenders

- Non-attenders scored significantly better on six

Non-attenders were invited measures of perceived to a health check but were not interviewed

\section{health status and used less} accident and emergency services and preventive health care than attenders

\begin{tabular}{|c|c|c|c|c|}
\hline 27 & Wall, M. & 2004 & $\begin{array}{l}\text { Non-participants in a } \\
\text { preventive health } \\
\text { examination for } \\
\text { cardiovascular disease: } \\
\text { characteristics, reasons for } \\
\text { nonparticipation, and } \\
\text { willingness to participate in } \\
\text { the future }\end{array}$ & $\begin{array}{l}\text { Sweden } \\
\text { Ockelbo project } \\
309 \text { persons aged } 35 \text { or } \\
40 y r s \text { were invited to } \\
\text { participate in a health } \\
\text { examination }\end{array}$ \\
\hline
\end{tabular}

Quasi-experimental

Preventive health examination

Follow up questionnaire mailed to nonparticipants
- 237 persons (76.7\%)

participated

- Of 72 non-attenders at the health examination, 53 (73.6\%) responded to the questionnaire, 14 (19.4\%) agreed to a telephone interview and 5 (6.9\%) did not respond 


\begin{tabular}{llll}
\hline 28 & Cherrington, $2007 \begin{array}{l}\text { Do adults who believe in } \\
\text { periodic health } \\
\text { examinations receive more } \\
\text { clinical preventive services? }\end{array}$ & America & Telephone survey \\
& 4879 respondents & $\begin{array}{l}\text { Telephone survey } \\
\text { Logistic regression analysis } \\
\text { of phone survey to assess } \\
\text { attitudes towards periodic } \\
\text { health examinations and } \\
\text { the receipt of preventive } \\
\text { services }\end{array}$
\end{tabular}

Follow up telephone interview with nonparticipants who did not respond to questionnaire
- The proportion of smokers was significantly higher in non-attenders $v$ attenders at the health check $(31.3 \%$ v $18.6 \%)$

- Reasons for nonattendance included: lack of time or hindrances at work (52\%), already in contact with health services (33\%), or because they felt healthy (21\%)

- However the majority of non-attenders (55\%) said they would be interested in attending in the future, $28 \%$ said they were not sure, and $16 \%$ said they would not be interested

- Non-endorsers of periodic health examinations

received less preventive services

- $8.5 \%(n=374)$ did not endorse annual periodic health examinations

- Non-endorsers tended to be male (odd ratio (OR) 1.64), younger (OR 0.87), white (OR 2.91), to have at least some college education (OR 1.43) and feel healthy (1.85)

- $56 \%$ of non-endorsers had received a cholestero check in the previous 5 years compared to $81 \%$ of endorsers

\begin{tabular}{|c|c|c|c|c|c|c|}
\hline \multirow[t]{5}{*}{29} & \multirow[t]{5}{*}{$\begin{array}{l}\text { Karwalajtys, } \\
\text { T. }\end{array}$} & \multirow[t]{5}{*}{2005} & \multirow{5}{*}{$\begin{array}{l}\text { A randomized trial of mail } \\
\text { vs. telephone invitation to } \\
\text { a community-based } \\
\text { cardiovascular health } \\
\text { awareness program for } \\
\text { older family practice } \\
\text { patients }\end{array}$} & Canada & Prospective & $\begin{array}{l}\text { - } 58.3 \% \text { of invited patients } \\
\text { attended }\end{array}$ \\
\hline & & & & 1 family physician practice & $\begin{array}{l}\text { randomised trial of } \\
\text { invitation to attend } \\
\text { community based by mail } \\
\text { or telephone }\end{array}$ & $\begin{array}{l}\text { - Patients invited by phone } \\
\text { were more likely to attend } \\
\text { than those by mail }(72.3 \% \\
\vee 44.0 \%)\end{array}$ \\
\hline & & & & 5 community pharmacies & & \multirow{3}{*}{$\begin{array}{l}\text { - Patients with a family } \\
\text { history of cardiovascular } \\
\text { disease were significantly } \\
\text { more likely to attend }\end{array}$} \\
\hline & & & & $\begin{array}{l}\text { Telephone and mailed } \\
\text { invitation }\end{array}$ & & \\
\hline & & & & 235 patients aged 65+ & Health record review & \\
\hline \multirow[t]{4}{*}{30} & \multirow[t]{4}{*}{ Hsu, H.Y. } & \multirow[t]{4}{*}{2001} & \multirow{4}{*}{$\begin{array}{l}\text { The relationships between } \\
\text { health beliefs and } \\
\text { utilization of free health } \\
\text { examinations in older } \\
\text { people living in a } \\
\text { community setting in } \\
\text { Taiwan }\end{array}$} & Taiwan & Cross-sectional survey & \multirow[b]{2}{*}{$\begin{array}{l}\text { - Higher uptake of health } \\
\text { examination in those with } \\
\text { higher education and } \\
\text { socio-economic status, and } \\
\text { those with increased family } \\
\text { support ( } 6 \% \text { of users lived } \\
\text { alone compared to } 13 \% \text { of } \\
\text { non-users) }\end{array}$} \\
\hline & & & & $\begin{array}{l}\text { Free health examination in } \\
\text { over } 65 \mathrm{~s}\end{array}$ & $\begin{array}{l}\text { Stratified random } \\
\text { systematic sample of } 200 \\
\text { men and women were } \\
\text { given a } 17 \text { item health } \\
\text { belief scale to complete }\end{array}$ & \\
\hline & & & & 100 participants & & \multirow{2}{*}{$\begin{array}{l}\text { - Users perceived a higher } \\
\text { level of seriousness and } \\
\text { susceptibility to ill health } \\
\text { than non-users }\end{array}$} \\
\hline & & & & 100 nonparticipants & & \\
\hline 31 & Bowden, R. G. & 2001 & $\begin{array}{l}\text { Comparisons of cholesterol } \\
\text { screening participants and }\end{array}$ & America & & $\begin{array}{l}\text { - Participants were more } \\
\text { likely to be male }(68.5 \% \mathrm{v}\end{array}$ \\
\hline
\end{tabular}


Table 4 Summary of included studies (Continued)

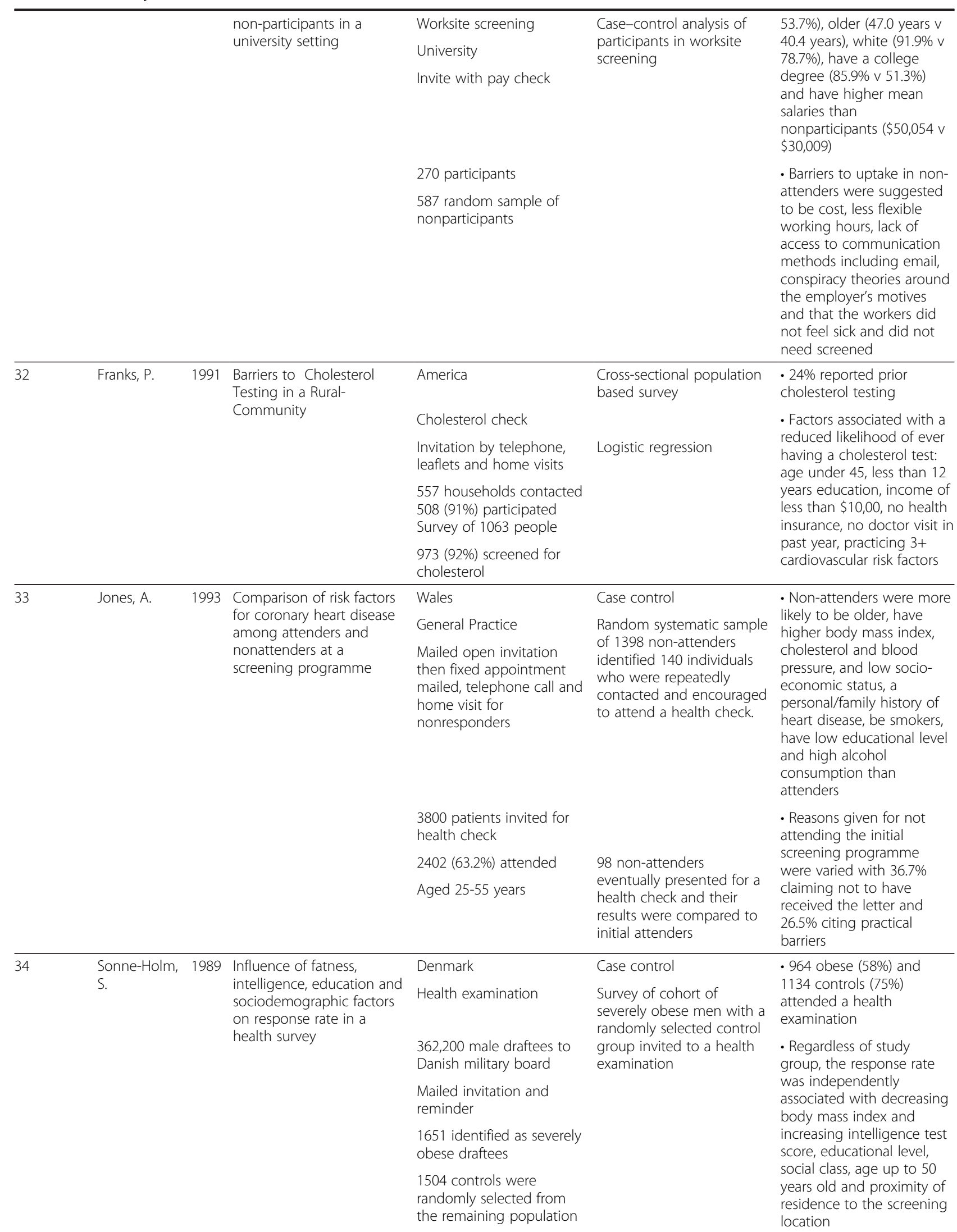


Table 4 Summary of included studies (Continued)

\begin{tabular}{|c|c|c|c|c|c|c|}
\hline \multirow[t]{4}{*}{35} & \multirow[t]{4}{*}{ Walker, M. } & \multirow[t]{4}{*}{1987} & \multirow{4}{*}{$\begin{array}{l}\text { Non-participation and } \\
\text { mortality in a prospective } \\
\text { study of cardiovascular } \\
\text { disease }\end{array}$} & UK & $\begin{array}{l}\text { British Regional Heart } \\
\text { Study }\end{array}$ & $\begin{array}{l}\text { - } 7735 \text { men }(74.3 \%) \\
\text { participated in the study }\end{array}$ \\
\hline & & & & $\begin{array}{l}\text { Comparison of } \\
\text { characteristics and } \\
\text { mortality levels of } \\
\text { participants and non- } \\
\text { participants in clinical }\end{array}$ & \multirow[t]{3}{*}{$\begin{array}{l}\text { Prospective study of } \\
\text { cardiovascular disease in } \\
\text { middle aged men }\end{array}$} & $\begin{array}{l}\text { - Non-participants had a } \\
\text { significantly higher relative } \\
\text { risk of death during the } \\
\text { first three years after the } \\
\text { screening date }\end{array}$ \\
\hline & & & & & & \multirow{2}{*}{$\begin{array}{l}\text { - Non-participants were } \\
\text { more likely to be younger, } \\
\text { unmarried and less skilled } \\
\text { workers than participants }\end{array}$} \\
\hline & & & & $\begin{array}{l}\text { Sample of } 10412 \text { men } \\
\text { aged } 40-59 \text { years }\end{array}$ & & \\
\hline \multirow[t]{6}{*}{36} & \multirow{6}{*}{$\begin{array}{l}\text { Thorogood, } \\
\text { M. }\end{array}$} & \multirow[t]{6}{*}{1993} & \multirow{6}{*}{$\begin{array}{l}\text { Factors affecting response } \\
\text { to an invitation to attend } \\
\text { for a health check }\end{array}$} & UK & Quasi-experimental & . 2205 attended (82.3\%) \\
\hline & & & & 5 General Practices & \multirow{5}{*}{$\begin{array}{l}\text { Postal questionnaire before } \\
\text { invite to attend a health } \\
\text { check and subsequent } \\
\text { record of attendance }\end{array}$} & $\begin{array}{l}\text { - Non-attendance was } \\
\text { higher in males than } \\
\text { females ( } 21 \% \vee 15 \%)\end{array}$ \\
\hline & & & & $\begin{array}{l}\text { Invitation by mail or } \\
\text { telephone, or } \\
\text { opportunistically plus up } \\
\text { to } 3 \text { reminders }\end{array}$ & & \multirow{2}{*}{$\begin{array}{l}\text { - Non-attenders were more } \\
\text { likely to be single than } \\
\text { married }(24 \% \vee 16 \%) \text {, } \\
\text { manual rather non-manual } \\
\text { workers }(21 \% \vee 15 \%) \text {, living } \\
\text { in rented accommodation } \\
\text { rather than homeowners } \\
(29 \% \vee 16 \%) \text { and not have } \\
\text { access to a car rather than } \\
\text { be a car user }(27 \% \vee 16 \%)\end{array}$} \\
\hline & & & & $\begin{array}{l}2678 \text { patients aged } 35-64 \\
\text { were invited to attend a } \\
\text { health check }\end{array}$ & & \\
\hline & & & & & & $\begin{array}{l}\text { - Non-attenders were less } \\
\text { healthy than attenders as } \\
\text { shown by following odd } \\
\text { ratios: } 1.74 \text { smokers, } 1.07 \\
\text { heavy drinkers, } 1.91 \text { less } \\
\text { healthy diet, } 1.50 \text { for obese } \\
\text { patients }\end{array}$ \\
\hline & & & & & & $\begin{array}{l}\text { - Attenders were more } \\
\text { likely to visit their GP } \\
\text { frequently and indicate a } \\
\text { willingness to change their } \\
\text { behaviour }\end{array}$ \\
\hline \multirow[t]{5}{*}{37} & \multirow[t]{5}{*}{ Dignan, M. B. } & \multirow[t]{5}{*}{1995} & \multirow{5}{*}{$\begin{array}{l}\text { Factors associated with } \\
\text { participation in a } \\
\text { preventive cardiology } \\
\text { service by patients with } \\
\text { coronary heart disease }\end{array}$} & America & \multirow[t]{3}{*}{$\begin{array}{l}\text { Prospective cohort/ } \\
\text { Qualitative }\end{array}$} & $\begin{array}{l}\text { - } 24 \text { patients (39\%) } \\
\text { attended the clinic }\end{array}$ \\
\hline & & & & Cardiology clinic & & \multirow{2}{*}{$\begin{array}{l}\text { - No statistically significant } \\
\text { demographic differences } \\
\text { were found between } \\
\text { attenders and non- } \\
\text { attenders }\end{array}$} \\
\hline & & & & $\begin{array}{l}\text { Face to face open } \\
\text { invitation and follow up } \\
\text { letter }\end{array}$ & & \\
\hline & & & & & Telephone interviews & \multirow[b]{2}{*}{$\begin{array}{l}\text { - Patients who attributed } \\
\text { their hospitalisation to a } \\
\text { heart attack or coronary } \\
\text { bypass surgery were more } \\
\text { likely to attend the clinic } \\
\text { than those who attributed } \\
\text { admission to chest pain or } \\
\text { for diagnostic reasons }\end{array}$} \\
\hline & & & & 62 patients & $\begin{array}{l}\text { Follow up of patients who } \\
\text { were hospitalised for heart } \\
\text { related conditions to } \\
\text { assess reasons for } \\
\text { nonattendance at } \\
\text { secondary prevention clinic }\end{array}$ & \\
\hline \multirow[t]{4}{*}{38} & \multirow[t]{4}{*}{ Griffiths, C. } & \multirow[t]{4}{*}{1994} & \multirow{4}{*}{$\begin{array}{l}\text { Registration health checks: } \\
\text { Inverse care in the inner } \\
\text { city? }\end{array}$} & UK & Survey & \multirow{3}{*}{$\begin{array}{l}\text { - Non-attenders were } \\
\text { significantly more likely to } \\
\text { be unemployed, African, } \\
\text { heavy smokers and of } \\
\text { lower social class than } \\
\text { attenders. }\end{array}$} \\
\hline & & & & 7 GP practices & Questionnaire analysis & \\
\hline & & & & $\begin{array}{l}\text { Face to face open } \\
\text { invitation }\end{array}$ & & \\
\hline & & & & $\begin{array}{l}356 \text { patients: } 101 \\
\text { declined/provided } \\
\text { inadequate data }\end{array}$ & & $\begin{array}{l}\text { - Demonstrated that } \\
\text { invitations to health checks } \\
\text { given in an unselected way } \\
\text { are least likely to engage } \\
\text { with those in most need }\end{array}$ \\
\hline
\end{tabular}


Table 4 Summary of included studies (Continued)

Of the remaining 256

patients, 118 attended a

health check (46\%)

\begin{tabular}{|c|c|c|c|c|c|}
\hline 39 & Wilson, S. & 1997 & $\begin{array}{l}\text { Health beliefs of blue collar } \\
\text { workers: increasing self } \\
\text { efficacy and removing } \\
\text { barriers }\end{array}$ & $\begin{array}{l}\text { USA } \\
\text { Health beliefs of } \\
\text { participants and non- } \\
\text { participants in worksite } \\
\text { blood pressure and } \\
\text { cholesterol screening }\end{array}$ & $\begin{array}{l}\text { Cross-sectional, descriptive, } \\
\text { expost facto questionnaire }\end{array}$ \\
\hline & & & & $\begin{array}{l}\text { Convenience sample } 200 \\
\text { blue collar workers }\end{array}$ & \\
\hline 40 & Boshuizen, & 2006 & Non-response in a survey & Netherlands & Logistic regression of \\
\hline & H. C. & & $\begin{array}{l}\text { of cardiovascular risk } \\
\text { factors in the Dutch } \\
\text { population: Determinants } \\
\text { and resulting biases }\end{array}$ & Health examination & $\begin{array}{l}\text { determinants of } \\
\text { participation in a health } \\
\text { examination survey in } \\
\text { previous participants in a }\end{array}$ \\
\hline & & & & $\begin{array}{l}3699 \text { participants from a } \\
\text { sample of }\end{array}$ & health interview study \\
\hline & & & & $\begin{array}{l}12786 \text { previous } \\
\text { participants }\end{array}$ & \\
\hline
\end{tabular}

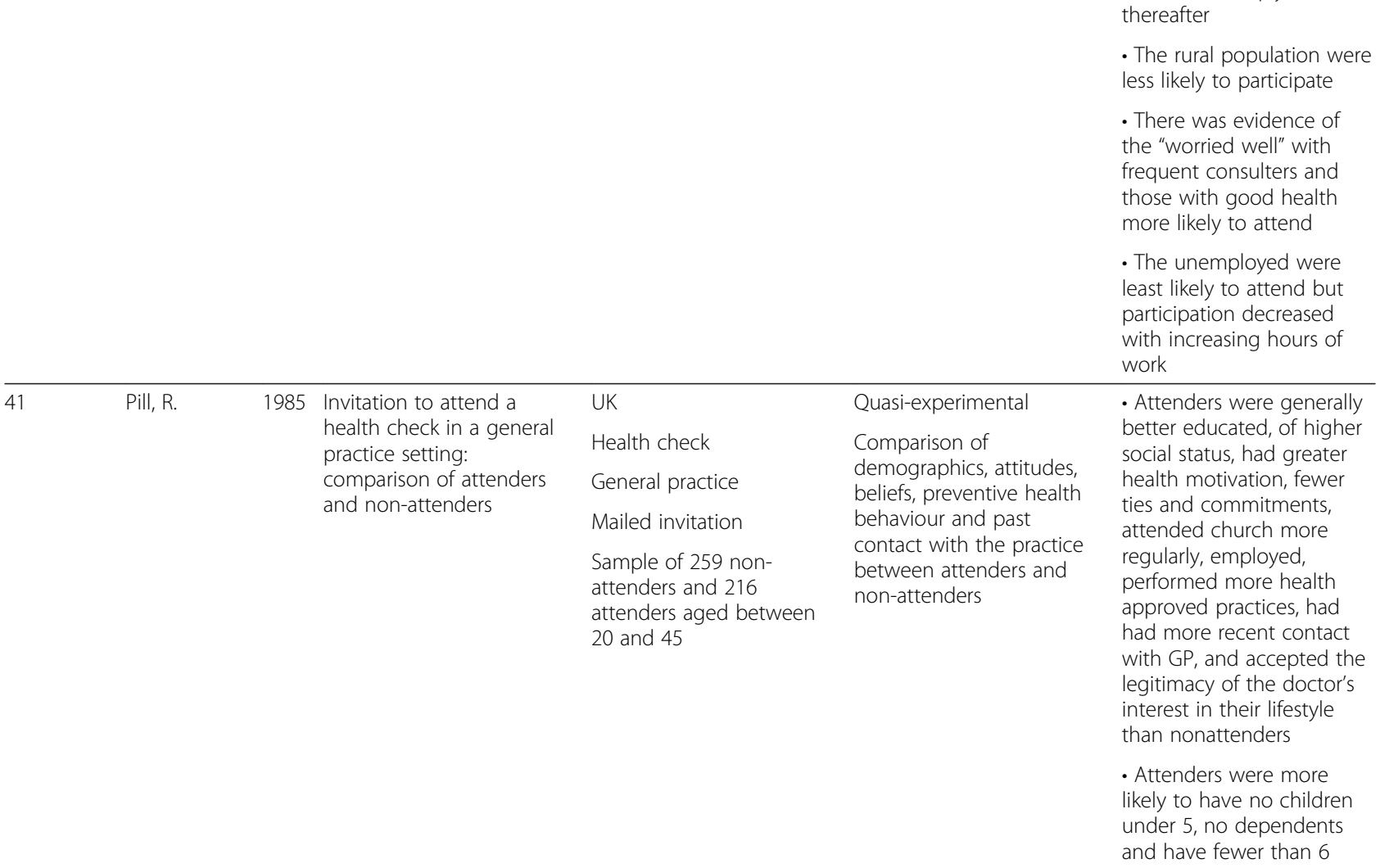


Table 4 Summary of included studies (Continued)

\begin{tabular}{|c|c|c|c|c|c|c|}
\hline & & & & & & $\begin{array}{l}\text { contacts a month with } \\
\text { friends or relatives than } \\
\text { nonattenders }\end{array}$ \\
\hline & & & & & & $\begin{array}{l}\text { - Non-attendance was } \\
\text { associated with greater } \\
\text { perceived support from } \\
\text { family and friends }\end{array}$ \\
\hline \multirow[t]{5}{*}{42} & \multirow[t]{5}{*}{ Persson, L. G. } & \multirow[t]{5}{*}{1994} & \multirow{5}{*}{$\begin{array}{l}\text { A Study of Men Aged 33- } \\
42 \text { in Habo, Sweden with } \\
\text { Special Reference to } \\
\text { Cardiovascular Risk-Factors }\end{array}$} & Sweden & Quasi-experimental & \multirow{2}{*}{$\begin{array}{l}\text { - } 652 \text { men }(86.1 \%) \text { had } \\
\text { attended after one mail } \\
\text { invitation }\end{array}$} \\
\hline & & & & Health check & \multirow{4}{*}{$\begin{array}{l}\text { Follow up of non-attenders } \\
\text { by mailed questionnaire } \\
\text { and telephone }\end{array}$} & \\
\hline & & & & $\begin{array}{l}\text { Postal invitation plus two } \\
\text { reminders }\end{array}$ & & \multirow{2}{*}{$\begin{array}{l}\text { - Of } 105 \text { non-participants, } \\
16 \text { were known high } \\
\text { consumers of health care, } \\
40 \text { had recently had a } \\
\text { health examination (mostly } \\
\text { at work) and } 49 \text { were not } \\
\text { interested in a health } \\
\text { check }\end{array}$} \\
\hline & & & & \multirow[t]{2}{*}{$\begin{array}{l}757 \text { men aged } 33-42 \text { were } \\
\text { invited to attend for a } \\
\text { health check }\end{array}$} & & \\
\hline & & & & & & $\begin{array}{l}\text { - Non-attenders were more } \\
\text { likely to be single, smokers, } \\
\text { on the sick list, on a lower } \\
\text { income or more often } \\
\text { unemployed than } \\
\text { attenders }\end{array}$ \\
\hline \multirow[t]{4}{*}{43} & \multirow{4}{*}{$\begin{array}{l}\text { Christensen, } \\
\text { B. }\end{array}$} & \multirow[t]{4}{*}{1995} & \multirow{4}{*}{$\begin{array}{l}\text { Characteristics of attenders } \\
\text { and non-attenders at } \\
\text { health examinations for } \\
\text { ischaemic heart disease in } \\
\text { general practice }\end{array}$} & Denmark & Quasi-experimental study & \multirow{2}{*}{$\begin{array}{l}\text { - Attendance was higher in } \\
\text { free health examinations } \\
\text { than those which charged } \\
\text { a fee }(66 \% \vee 37 \%) \\
\text { - Attendance was } \\
\text { significantly lower in single } \\
\text { men than cohabitants }\end{array}$} \\
\hline & & & & 65 General Practices & $\begin{array}{l}\text { Multi-practice study and } \\
\text { questionnaires to assess } \\
\text { the influence of a fee to } \\
\text { attend a health } \\
\text { examination }\end{array}$ & \\
\hline & & & & $\begin{array}{l}\text { Health examinations for } \\
\text { ischaemic heart disease }\end{array}$ & & $\begin{array}{l}\text { - Whether the service was } \\
\text { free or not was the biggest }\end{array}$ \\
\hline & & & & $\begin{array}{l}\text { Letter invitation } 2452 \text { men } \\
\text { aged } 40-49 \text { years were } \\
\text { invited to attend }\end{array}$ & & $\begin{array}{l}\text { predictor of attendance as } \\
\text { health beliefs of attenders } \\
\text { and non-attenders were } \\
\text { similar }\end{array}$ \\
\hline \multirow[t]{5}{*}{44} & \multirow[t]{5}{*}{ Difford, F. } & \multirow[t]{5}{*}{1987} & \multirow{5}{*}{$\begin{array}{l}\text { Continuous opportunistic } \\
\text { and systematic screening } \\
\text { for hypertension with } \\
\text { computer help: Analysis of } \\
\text { nonresponders }\end{array}$} & England & Programme evaluation & \multirow{2}{*}{$\begin{array}{l}\text { - } 2354 \text { patients }(92 \%) \text { had } \\
\text { blood pressure recorded in } \\
\text { the previous } 5 \text { years after } 2 \\
\text { years }\end{array}$} \\
\hline & & & & General practice & Audit of medical records & \\
\hline & & & & $\begin{array}{l}\text { Opportunistic } \\
\text { hypertension screening }\end{array}$ & $\begin{array}{l}\text { Analysis of characteristics } \\
\text { of } 192 \text { nonresponders }\end{array}$ & $\begin{array}{l}\text { - Those who had been } \\
\text { screened have higher } \\
\text { consultation rates ( } 6 x \\
\text { greater) than non- } \\
\text { responders }\end{array}$ \\
\hline & & & & \multirow[t]{2}{*}{$\begin{array}{l}2546 \text { patients aged } 40-64 \\
\text { years }\end{array}$} & & $\begin{array}{l}\text { - There was no difference } \\
\text { by distance to the practice } \\
\text { or number of years } \\
\text { registered with the practice }\end{array}$ \\
\hline & & & & & & $\begin{array}{l}\text { - The only significant } \\
\text { difference was that } \\
\text { nonresponders were the } \\
\text { only people in a household } \\
\text { registered with a practice } \\
\text { which was interpreted that } \\
\text { they were either single or } \\
\text { had a lack of need to } \\
\text { identify with the "family" } \\
\text { doctor }\end{array}$ \\
\hline 45 & $\begin{array}{l}\text { Engebretson, } \\
\text { J. }\end{array}$ & 2005 & $\begin{array}{l}\text { Participation in Community } \\
\text { Health Screenings: A } \\
\text { Qualitative Evaluation }\end{array}$ & America & Qualitative Focus groups & $\begin{array}{l}\text { - Described domains of } \\
\text { motivation for } \\
\text { presentation: }\end{array}$ \\
\hline
\end{tabular}


Table 4 Summary of included studies (Continued)

\begin{tabular}{|c|c|c|c|c|c|c|}
\hline & & & & $\begin{array}{l}\text { Participants in screenings } \\
\text { at } 5 \text { settings: }\end{array}$ & 5 with attenders & $\begin{array}{l}\text { - Self-care orientations (e.g. } \\
\text { self-assessment/no } \\
\text { perceived need) }\end{array}$ \\
\hline & & & & University employees & 1 with nonattenders & $\begin{array}{l}\text { - Interpersonal influences } \\
\text { (e.g. endorsement by } \\
\text { others/fear of } \\
\text { embarrassment) }\end{array}$ \\
\hline & & & & & & $\begin{array}{l}\text { - Accessibility (e.g. } \\
\text { convenience/lack of time) }\end{array}$ \\
\hline & & & & County fair attendees & & - Overlap of facilitators and \\
\hline & & & & $\begin{array}{l}\text { Senior citizen centre } \\
\text { clientele }\end{array}$ & & $\begin{array}{l}\text { barriers to participation; } \\
\text { what motivated one } \\
\text { participant to attend may }\end{array}$ \\
\hline & & & & Local industry employees & & act as a barrier to another \\
\hline & & & & University student & & \\
\hline & & & & Group of non-attenders & & \\
\hline 46 & Harpole, L.H. & 2000 & $\begin{array}{l}\text { Feasibility of a tailored } \\
\text { intervention to improve }\end{array}$ & America & $\begin{array}{l}\text { Survey to identify } \\
\text { outstanding preventive }\end{array}$ & $\begin{array}{l}\text { - } 591 \text { women }(67 \%) \\
\text { returned the survey }\end{array}$ \\
\hline & & & $\begin{array}{l}\text { preventive care use in } \\
\text { women }\end{array}$ & $\begin{array}{l}\text { Survey mailed to } 893 \\
\text { women aged } 50-55\end{array}$ & health care needs & $\begin{array}{l}\text { - } 76 \% \text { were in need of one } \\
\text { or more preventive health } \\
\text { service }\end{array}$ \\
\hline & & & & & & $\begin{array}{l}\text { - } 16 \% \text { were in need of } 3 \text { or } \\
\text { more }\end{array}$ \\
\hline & & & & & & $\begin{array}{l}\text { - Women with increasing } \\
\text { need for preventive health } \\
\text { services were more likely to } \\
\text { be non-white, earn less, } \\
\text { have a lower level of } \\
\text { education, and be less } \\
\text { satisfied with their } \\
\text { health care }\end{array}$ \\
\hline 47 & Norman, P. & 1991 & Predicting attendance at & UK & Programme evaluation & • $131(59.3 \%)$ \\
\hline & & & $\begin{array}{l}\text { health screening: } \\
\text { Organizational factors and } \\
\text { patients' health beliefs }\end{array}$ & General Practice & $\begin{array}{l}\text { A health belief } \\
\text { questionnaire was sent to } \\
\text { sample of } 221 \text { patients } \\
\text { who were subsequently } \\
\text { invited for screening }\end{array}$ & $\begin{array}{l}\text { questionnaires were } \\
\text { returned. From this group } \\
98 \text { attended and } 33 \text { did } \\
\text { not attend the subsequent } \\
\text { health check }\end{array}$ \\
\hline & & & & Health check & & \\
\hline & & & & $\begin{array}{l}\text { Mailed fixed appointment } \\
\text { or invited opportunistically }\end{array}$ & & $\begin{array}{l}\text { - The two invite methods } \\
\text { had similar attendance } \\
\text { rates but the letter invite } \\
\text { was more efficient, as } \\
\text { opportunistic screening } \\
\text { relied on patients } \\
\text { presenting at their GP } \\
\text { before they could be } \\
\text { invited }\end{array}$ \\
\hline & & & & $\begin{array}{l}325 \text { patients aged } \\
\text { between } 30 \text { and } 50\end{array}$ & & $\begin{array}{l}\text { - Opportunistic screening } \\
\text { was slightly biased in } \\
\text { favour of females }\end{array}$ \\
\hline & & & & Health belief questionnaire & $\begin{array}{l}11 \text { patients were } \\
\text { interviewed directly after } \\
\text { their screening } \\
\text { appointment }\end{array}$ & $\begin{array}{l}\text { - Attenders were more } \\
\text { likely to report cutting back } \\
\text { on daily activities when ill } \\
\text { and believe in the } \\
\text { seriousness of high blood } \\
\text { pressure and weight } \\
\text { problems }\end{array}$ \\
\hline & & & & & & $\begin{array}{l}\text { - Non-attenders were } \\
\text { found to be more worried } \\
\text { about the screening } \\
\text { appointment and } \\
\text { perceived more barriers to } \\
\text { attendance }\end{array}$ \\
\hline
\end{tabular}


Table 4 Summary of included studies (Continued)

\begin{tabular}{|c|c|c|c|c|c|c|}
\hline \multirow[t]{4}{*}{48} & \multirow[t]{4}{*}{ Shiloh, S. } & \multirow[t]{4}{*}{1997} & \multirow{4}{*}{$\begin{array}{l}\text { Correlates of health } \\
\text { screening utilization: The } \\
\text { roles of health beliefs and } \\
\text { selfregulation motivation }\end{array}$} & \multirow{4}{*}{$\begin{array}{l}\text { A convenience sample of } \\
252 \text { asymptomatic } \\
\text { individuals were invited to } \\
\text { participate in one of four } \\
\text { screening programmes: } \\
\text { dental check up, blood } \\
\text { pressure measurement } \\
\text { and cholesterol testing, } \\
\text { pap smear or } \\
\text { mammography }\end{array}$} & Quasi-experimental & $\begin{array}{l}\text {. } 137(54 \%) \text { attended and } \\
115(46 \%) \text { did not attend }\end{array}$ \\
\hline & & & & & $\begin{array}{l}\text { Analysis of participants in a } \\
\text { screening programme }\end{array}$ & $\begin{array}{l}\text { - Motivations and health } \\
\text { beliefs varied by screening } \\
\text { programme }\end{array}$ \\
\hline & & & & & $\begin{array}{l}\text { Questionnaire tailored to } \\
\text { specific screening } \\
\text { programme and whether } \\
\text { individual attended or did } \\
\text { not attend }\end{array}$ & $\begin{array}{l}\text { - Non-attenders were more } \\
\text { likely to justify their } \\
\text { nonattendance behaviour } \\
\text { with danger control } \\
\text { motivations than fear } \\
\text { control ones }\end{array}$ \\
\hline & & & & & & $\begin{array}{l}\text { - } 61 \% \text { non-attenders did } \\
\text { not believe in the efficacy } \\
\text { of screening in reducing } \\
\text { their illness threat whereas } \\
39 \% \text { were too afraid of the } \\
\text { possible results to attend }\end{array}$ \\
\hline \multirow[t]{6}{*}{49} & \multirow[t]{6}{*}{ Norman, P. } & \multirow[t]{6}{*}{1993} & \multirow{6}{*}{$\begin{array}{l}\text { The role of social cognition } \\
\text { models in predicting } \\
\text { attendance at health } \\
\text { checks }\end{array}$} & UK & \multirow[t]{2}{*}{$\begin{array}{l}\text { Prospective survey/ } \\
\text { programme evaluation }\end{array}$} & $\begin{array}{l}\text { - } 419 \text { patients were sent } \\
\text { open invitations }\end{array}$ \\
\hline & & & & General Practice & & $\begin{array}{l}\text { - } 399 \text { patients were sent } \\
\text { fixed appointments }\end{array}$ \\
\hline & & & & $\begin{array}{l}\text { Mailed invitation with } \\
\text { fixed appointment time or } \\
\text { open invitation }\end{array}$ & $\begin{array}{l}\text { Health belief } \\
\text { questionnaires sent before } \\
\text { patients received invite } \\
\text { letters }\end{array}$ & $\begin{array}{l}\text { - } 433 / 818 \text { patients attended } \\
\text { a health check; } 69.7 \% \text { of } \\
\text { those sent fixed } \\
\text { appointments and } 37.1 \% \\
\text { sent open invitations } \\
\text { attended }\end{array}$ \\
\hline & & & & \multirow{3}{*}{$\begin{array}{l}818 \text { patients aged } \\
\text { between } 30 \text { and } 41 \text { were } \\
\text { invited to attend a health } \\
\text { check }\end{array}$} & Health check & - Questionnaire data \\
\hline & & & & & $\begin{array}{l}\text { Patients randomly } \\
\text { allocated to receive either } \\
\text { a letter of invitation with } \\
\text { either a fixed appointment } \\
\text { or an open invitation to } \\
\text { make their own } \\
\text { appointment }\end{array}$ & $\begin{array}{l}\text { showed that for those that } \\
\text { were sent a fixed } \\
\text { appointment, attenders } \\
\text { were more likely to place a } \\
\text { high value on health, to } \\
\text { believe health is influenced } \\
\text { by powerful others, to be } \\
\text { advised by referent groups } \\
\text { to attend, to believe in the } \\
\text { positive outcomes of } \\
\text { screening and to not be } \\
\text { affected by motivational } \\
\text { barriers than nonattenders }\end{array}$ \\
\hline & & & & & & $\begin{array}{l}\text { - For those sent an open } \\
\text { invitation, intention to } \\
\text { attend and perceived } \\
\text { control were independent } \\
\text { predictors of attendance } \\
\text { behaviour }\end{array}$ \\
\hline \multirow[t]{4}{*}{50} & \multirow[t]{4}{*}{ Norman, P. } & \multirow[t]{4}{*}{1991} & \multirow{4}{*}{$\begin{array}{l}\text { Patients' views on health } \\
\text { screening in general } \\
\text { practice }\end{array}$} & UK & Programme evaluation & - Of the 168 invited by \\
\hline & & & & General Practice & & attended a health check \\
\hline & & & & $\begin{array}{l}\text { Mailed fixed appointment } \\
\text { or invited opportunistically }\end{array}$ & $\begin{array}{l}\text { Patients randomly selected } \\
\text { to be invited to general } \\
\text { health screening in one of } \\
\text { two ways: }\end{array}$ & $\begin{array}{l}\text { - Only } 83 / 157 \text { patients had } \\
\text { been invited } \\
\text { opportunistically, but } \\
\text { attendance in those that } \\
\text { had been invited was } \\
74.7 \%\end{array}$ \\
\hline & & & & $\begin{array}{l}\text { Sample of } 379 \text { patients } \\
\text { aged } 30 \text { - } 50 \text { years, } 325 \\
\text { were invited after } \\
\text { exclusion of unsuitable } \\
\text { patients }\end{array}$ & & $\begin{array}{l}\text { - The remaining patients } \\
\text { who had not yet been } \\
\text { invited opportunistically } \\
\text { were sent a fixed } \\
\text { appointment which } \\
\text { produced } 55.4 \% \\
\text { attendance }\end{array}$ \\
\hline
\end{tabular}




\begin{tabular}{|c|c|c|c|c|c|c|}
\hline & & & & & $\begin{array}{l}\text { Letter with fixed } \\
\text { appointment }(n=168) \text { or } \\
\text { notes were tagged so } \\
\text { patient was invited } \\
\text { opportunistically to make } \\
\text { an appointment for a } \\
\text { health check when they }\end{array}$ & $\begin{array}{l}\text { - Those invited } \\
\text { opportunistically were } \\
\text { most likely to report that } \\
\text { keeping their appointment } \\
\text { time was easy, and were } \\
\text { least likely to change it. }\end{array}$ \\
\hline & & & & & $\begin{array}{l}\text { nealth check when they } \\
\text { presented at the practice } \\
\text { for another reason }(n=157)\end{array}$ & $\begin{array}{l}\text { - Those given fixed } \\
\text { appointments experienced }\end{array}$ \\
\hline & & & & & $\begin{array}{l}\text { Questionnaire was issued } \\
\text { after health check to assess } \\
\text { views of health check }\end{array}$ & $\begin{array}{l}\text { even if they were well } \\
\text { motivated }\end{array}$ \\
\hline & & & & & $\begin{array}{l}11 \text { patients were } \\
\text { interviewed }\end{array}$ & \\
\hline 51 & Nielsen, K. D. B. & 2004 & "You can't prevent & Denmark & Qualitative & - Reasons for non- \\
\hline & & & $\begin{array}{l}\text { everything anyway": A } \\
\text { qualitative study of beliefs }\end{array}$ & Health examination & Interview with sample of & $\begin{array}{l}\text { attendance: too busy, } \\
\text { healthy, recent contact }\end{array}$ \\
\hline & & & $\begin{array}{l}\text { and attitudes about } \\
\text { refusing health screening } \\
\text { in general practice }\end{array}$ & 6 men & $\begin{array}{l}18 \text { non-participants in a } \\
\text { randomised control } \\
\text { populationbased project }\end{array}$ & $\begin{array}{l}\text { with general practice, don't } \\
\text { want to know if ill, no } \\
\text { symptoms, major life } \\
\text { events, actual health } \\
\text { problems }\end{array}$ \\
\hline & & & & 12 women & $\begin{array}{l}\text { Non-participants were } \\
\text { sampled using stratified } \\
\text { purposeful techniques }\end{array}$ & $\begin{array}{l}\text { - They stressed the } \\
\text { importance of autonomy, } \\
\text { and that they would go to } \\
\text { see their doctor when they } \\
\text { needed to }\end{array}$ \\
\hline 52 & Norman, P. & 1989 & Intention to attend a & UK & Cross-sectional survey & - Initial questionnaires were \\
\hline & & & & & $\begin{array}{l}\text { Patients randomly selected } \\
\text { from practice list by age/ }\end{array}$ & $\begin{array}{l}\text { returned by } 1 / 8 \text { patients } \\
\text { (37\% response rate) }\end{array}$ \\
\hline & & & practice & $\begin{array}{l}\text { Questionnaire to assess } \\
\text { predictors of intention to } \\
\text { attend a health check }\end{array}$ & $\begin{array}{l}\text { sex bands ( } 25-30,35-40 \text {, } \\
45-50 \text { years) }\end{array}$ & $\begin{array}{l}\text { - Reminder questionnaire } \\
\text { returned a further } 97 \\
\text { replies. An additional } 29 \\
\text { questionnaires were } \\
\text { excluded due to incorrect } \\
\text { addresses or being } \\
\text { incompletely filled in. } \\
\text { Response rate was } 57 \% \\
\text { (n=275) }\end{array}$ \\
\hline & & & & 479 patients aged $25-50$ & Sent questionnaire & $\begin{array}{l}\text { - Those who intend to } \\
\text { attend a health check } \\
\text { placed a high value on } \\
\text { their health; believe in their } \\
\text { susceptibility to common } \\
\text { illnesses and the severity of } \\
\text { major illnesses. They } \\
\text { believe in the efficacy of } \\
\text { doctors and screening, } \\
\text { have someone to talk to } \\
\text { about problems and are } \\
\text { more likely to be married } \\
\text { or cohabiting. }\end{array}$ \\
\hline & & & & & & $\begin{array}{l}\text { - Those who are likely to } \\
\text { not attend have different } \\
\text { attitudes towards screening } \\
\text { and believe it would be } \\
\text { too much effort or feel } \\
\text { concerned about aspects } \\
\text { of screening }\end{array}$ \\
\hline
\end{tabular}


Table 4 Summary of included studies (Continued)

\begin{tabular}{|c|c|c|c|c|c|c|}
\hline \multirow[t]{5}{*}{53} & \multirow[t]{5}{*}{ Williams, A } & \multirow[t]{5}{*}{2001} & \multirow{5}{*}{$\begin{array}{l}\text { Cultural sensitivity and day } \\
\text { care workers: examination } \\
\text { of a worksite based } \\
\text { cardiovascular disease } \\
\text { prevention project }\end{array}$} & USA & \multirow{2}{*}{$\begin{array}{l}\text { Programme evaluation of } \\
\text { screening initiative over } \\
\text { three years }\end{array}$} & \multirow[b]{2}{*}{$\begin{array}{l}\text { - Participation rates were } \\
\text { increased from } 26 \% \text { to } 73 \% \\
\text { over the duration of the } \\
\text { project by adapting } \\
\text { recruitment strategies to } \\
\text { the target group's cultural } \\
\text { values and lifestyles, and } \\
\text { building trust }\end{array}$} \\
\hline & & & & $\begin{array}{l}\text { "Healthier people health } \\
\text { risk appraisal" }\end{array}$ & & \\
\hline & & & & \multirow[t]{2}{*}{$\begin{array}{l}\text { Strategy to recruit child } \\
\text { day care workers in a } \\
\text { cardiovascular disease } \\
\text { screening and risk } \\
\text { reduction programme }\end{array}$} & \multirow[t]{3}{*}{ Interview with participants } & $\begin{array}{l}-70 \% \text { of participants cited } \\
\text { convenience (because it } \\
\text { was offered at their } \\
\text { workplace) and the fact } \\
\text { that it was free as } \\
\text { motivators to attend }\end{array}$ \\
\hline & & & & & & $\begin{array}{l}\text { - A lack of knowledge of } \\
\text { cardiovascular risk was } \\
\text { identified in this } \\
\text { population as just over } \\
10 \% \text { of participants were } \\
\text { aware of their blood } \\
\text { pressure or blood } \\
\text { cholesterol }\end{array}$ \\
\hline & & & & $N=84$ & & $\begin{array}{l}\text { - Non-participants had } \\
\text { been tested recently or } \\
\text { were not interested in the } \\
\text { screening at the time it } \\
\text { was offered }\end{array}$ \\
\hline \multirow[t]{4}{*}{54} & \multirow[t]{4}{*}{ Ornstein, S. M } & \multirow[t]{4}{*}{1993} & \multirow{4}{*}{$\begin{array}{l}\text { Barriers to adherence to } \\
\text { preventive services } \\
\text { reminder letters: the } \\
\text { patient's perspective }\end{array}$} & USA & \multirow{2}{*}{$\begin{array}{l}\text { Qualitative Telephone } \\
\text { survey }(n=307)\end{array}$} & \multirow{2}{*}{$\begin{array}{l}\text { - } 307 \text { patients were } \\
\text { surveyed by telephone to } \\
\text { assess reasons for non- } \\
\text { response to a letter for } \\
\text { screening }\end{array}$} \\
\hline & & & & Cholesterol screening & & \\
\hline & & & & \multirow[t]{2}{*}{$\begin{array}{l}\text { Reminder letters sent to } \\
1077 \text { patients }\end{array}$} & \multirow[t]{2}{*}{$\begin{array}{l}\text { Focus groups of non- } \\
\text { responders to a reminder } \\
\text { letter }(n=27)\end{array}$} & $\begin{array}{l}\text { - } 154(50.2 \%) \text { did not recall } \\
\text { receiving the letter, } 84 \\
(27.4 \%) \text { recalled receiving } \\
\text { the letter but not its } \\
\text { content, } 69(22.5 \%) \text { recalled } \\
\text { both }\end{array}$ \\
\hline & & & & & & $\begin{array}{l}\text { - Highlighted the } \\
\text { importance of the format } \\
\text { and content of reminder } \\
\text { letters to improve uptake } \\
\text { of cholesterol checks by } \\
\text { making them } \\
\text { distinguishable from a bill, } \\
\text { conveying a personalised } \\
\text { message and addressing } \\
\text { logistical barriers }\end{array}$ \\
\hline \multirow[t]{3}{*}{55} & \multirow[t]{3}{*}{ Pill, R. } & \multirow[t]{3}{*}{1988} & \multirow{3}{*}{$\begin{array}{l}\text { Invitation to attend a } \\
\text { health check in a general } \\
\text { practice setting: the views } \\
\text { of a cohort of } \\
\text { nonattenders }\end{array}$} & UK & Qualitative & \multirow{2}{*}{$\begin{array}{l}\text { - } 236(91 \%) \text { recalled getting } \\
\text { the invitation, } 3 \% \text { could } \\
\text { not remember and } 6 \% \\
\text { denied ever receiving the } \\
\text { invitation }\end{array}$} \\
\hline & & & & \multirow{2}{*}{$\begin{array}{l}259 \text { men and women } \\
\text { aged } 20 \text { - } 45 \text { who did not } \\
\text { respond to a mailed } \\
\text { invitation for a health } \\
\text { check at General Practice }\end{array}$} & Interview of nonattenders & \\
\hline & & & & & & $\begin{array}{l}\text { - Reasons for non- } \\
\text { attendance: } 44 \% \text { were not } \\
\text { interested, } 24 \% \text { forgot to } \\
\text { attend, } 26 \% \text { cited crises at } \\
\text { home or work, } 11 \% \text { felt } \\
\text { screening was } \\
\text { inappropriate }\end{array}$ \\
\hline \multirow[t]{2}{*}{56} & \multirow[t]{2}{*}{$\begin{array}{l}\text { Thompson, } \\
\text { N. F. }\end{array}$} & \multirow[t]{2}{*}{1990} & \multirow{2}{*}{$\begin{array}{l}\text { Inviting infrequent } \\
\text { attenders to attend for a } \\
\text { health check: costs and } \\
\text { benefits }\end{array}$} & UK & Quasi-experimental & $\begin{array}{l}\text { - 17/94 patients (18\%) } \\
\text { attended }\end{array}$ \\
\hline & & & & General Practice & $\begin{array}{l}\text { Audit of sample of practice } \\
\text { records ( } n=1488) \text { to }\end{array}$ & $\begin{array}{l}\text { - Of the remaining } 77 \\
\text { patients, } 3 \text { had moved }\end{array}$ \\
\hline
\end{tabular}


Table 4 Summary of included studies (Continued)

\begin{tabular}{|c|c|c|c|c|c|c|}
\hline & & & & $\begin{array}{l}\text { Mailed fixed appointment } \\
94 \text { patients who had not } \\
\text { attended general practice } \\
\text { within the previous } 3 \\
\text { years were invited for a } \\
\text { health check }\end{array}$ & $\begin{array}{l}\text { identify all 3- year } \\
\text { nonattenders ( } \mathrm{n}=114 \text { ) an } \\
\text { invitation including fixed } \\
\text { appointment time was } \\
\text { sent to } 94 \text { eligible patients }\end{array}$ & $\begin{array}{l}\text { home, } 28 \text { cancelled the } \\
\text { appointment and nothing } \\
\text { was heard from } 45 \text {, the } \\
\text { final patient had been } \\
\text { admitted for a myocardial } \\
\text { infarction before the } \\
\text { appointment }\end{array}$ \\
\hline & & & & & & $\begin{array}{l}\text { - Of those who cancelled, } 8 \\
\text { were working or studying } \\
\text { away from home, } 4 \text { found } \\
\text { the appointment time } \\
\text { unsuitable but did not } \\
\text { wish to rearrange and } 16 \\
\text { did not need or want an } \\
\text { appointment }\end{array}$ \\
\hline & & & & & & $\begin{array}{l}\text { - Those presenting were in } \\
\text { general healthy with low } \\
\text { levels of smoking and } \\
\text { alcohol consumption and } \\
\text { mild hypertension only } \\
\text { diagnosed in one patient. }\end{array}$ \\
\hline 57 & Hegarty, V. & 1995 & Reasons for nonresponse & UK & Letter to the editor & • 847 attended \\
\hline & & & among older adults & General practice & $\begin{array}{l}\text { describing study which } \\
\text { invited over } 75 \mathrm{~s} \text { for a }\end{array}$ & - 182 were untraceable \\
\hline & & & & $\begin{array}{l}1342 \text { invited for a health } \\
\text { check }\end{array}$ & health check & deceased) \\
\hline & & & & & & - 44 actively declined \\
\hline & & & & & & $\begin{array}{l}\text { - } 142 \text { attended after a } \\
\text { follow up telephone call }\end{array}$ \\
\hline & & & & & $\begin{array}{l}\text { Reasons for nonresponse } \\
\text { were assessed with a } \\
\text { questionnaire }\end{array}$ & $\begin{array}{l}\text { - } 120 \text { did not attend } \\
\text { because they had seen } \\
\text { their GP within last } 12 \\
\text { months }\end{array}$ \\
\hline & & & & & & $\begin{array}{l}\text { - } 7 \text { did not respond } \\
\text { because of ill health }\end{array}$ \\
\hline & & & & & & $\begin{array}{l}\text { - The variety of reasons for } \\
\text { non-response indicated } \\
\text { that non-attendance does } \\
\text { not always equate to poor } \\
\text { health }\end{array}$ \\
\hline 58 & Levine, J. A. & 1991 & Are patients in favour of & UK & Cross-sectional survey & - 315/375 (84\%) attenders \\
\hline & & & & General Practice & Questionnaire & $\begin{array}{l}\text { completed the } \\
\text { questionnaire }\end{array}$ \\
\hline & & & & $\begin{array}{l}375 \text { consecutive patients } \\
198 \text { individuals who had } \\
\text { not attended general } \\
\text { practice for } 12 \text { months }\end{array}$ & & $\begin{array}{l}\text { - 93/198 (47\%) non- } \\
\text { attenders completed the } \\
\text { questionnaire } \\
\text { - A significantly greater } \\
\text { proportion of attenders } \\
\text { (83\%) indicated they would } \\
\text { make an appointment and } \\
\text { attend for health screening } \\
\text { compared to nonattenders } \\
(66 \%)\end{array}$ \\
\hline & & & & & & $\begin{array}{l}\text { - } 33 \% \text { of attenders would } \\
\text { seek health screening even } \\
\text { if not contacted by their } \\
\text { doctor } v 16 \% \text { of } \\
\text { nonattenders }\end{array}$ \\
\hline
\end{tabular}


The tendency of women to present more than men (as evidenced earlier) persists regardless of marital status. Higher rates of attendance in women who were single, divorced or widowed $(79 \%)$ were found compared to men with equivalent marital status (65\%). Furthermore, the rates of attendance were $88 \%$ in married women and $84 \%$ in married men, indicating that being married appears to have a stronger effect on uptake in men [24]. Other studies have found no relationship between marital status and attendance rates $[39,41,46]$.

In general, white individuals were more likely to engage with preventive health services than individuals from other ethnic backgrounds [22,31,38,40,46]. However, ethnicity was only reported in a small proportion of the studies (Seven of 39 papers). Only one of these reported no difference according to race [39]. One paper reported a higher proportion of non-attenders at registration health checks were of African origin [38]. On the other hand, a large American survey $(n=4879)$ found that $9.6 \%$ of white people did not believe in periodic health examinations compared to $3.4 \%$ of black people, and that black people were more likely to have been screened for cholesterol in the past 5 years than white people [28].

\section{What are patients' reasons for not attending preventative health checks?}

The relationship between social cognitive factors and attendance behaviour was not straightforward as although health beliefs were found to affect uptake [47], the factors influencing the decisions of attenders and non-attenders may not necessarily reflect "opposite motivations of beliefs" [48]. To clarify, this meant that attenders may present for screening to reduce the fear or perceived danger of a condition, while non-attenders may have used the same rationale to not present, e.g. they did not feel at risk or were too frightened of the possible outcome if they did attend.

Despite this caveat, non-attenders were shown to value health less strongly, have lower self-efficacy, feel less in control of their health and be less likely to believe in the efficacy of screening $[39,49]$. Components of the health belief model were identified as significant predictors, with those who did not engage with services less likely to feel susceptible to ill health or perceive the conditions being screened for as serious as those who attended $[25,30,48]$.

Individuals may present in response to symptoms, a family history of the condition [29], or to seek reassurance [50]. Others are simply interested in their health, seek confirmation of a previous reading/monitor an existing condition or are worried well $[20,22,45]$. Those who do not present may have no perceived need for a health check: they may feel healthy or have an absence of symptoms $[27,33,51,52]$, are already in contact with the health service $[27,33,41,51,53]$, or have recently had a health check $[27,51,54]$. Alternatively, they are aware they are unhealthy and do not want to be told off and have to make lifestyle changes, or have a fear of what it might find $[26,28,31,47,51]$.

Fear acted as a barrier to uptake of screening in a number of ways, including: a fear of what the health check might find $[33,52,55]$, the belief that "what I don't know won't hurt me" [45] and that knowing wouldn't make them any happier [51], or the fear of the test results $[25,45]$ and their consequences [51]. Concerns related to the procedure itself were also apparent in relation to a fear of needles or a general fear of doctors or medical settings, anxiety about what the tests might involve [45,47] or the experience level of those carrying out the tests [45].

\section{What are the clinical needs and risk factors of those who present for health checks?}

Non-attenders had a greater proportion of cardiovascular risk factors than attenders. Smokers were less likely to attend than non-smokers $[21,23,25,27,32,33,36,38,42,46,56]$. Unhealthy lifestyle factors were important predictors of non-attendance, with odds ratios higher for smokers, heavy drinkers, and those with unhealthy diets and the obese [36]. However, one paper showed occasional smokers and ex-smokers were more likely to receive a check-up than non-smokers [21] and smokers with the intention of giving up were more likely to attend than those who did not want to [23].

A personal history but not family history of coronary heart disease (CHD) was significantly more common in non-attenders, as was a higher body mass index (BMI) [34], high cholesterol, systolic and diastolic blood pressure values [33].

Follow up of non-participants in a prospective study of cardiovascular disease found that this group were more likely to have died than participants in the three years following the health checks. The difference in the mortality rates between participants and non-participants was biggest in the youngest age group (40-44 year olds), indicating premature death. However, the mortality rates were not significantly different between these groups for cardiovascular disease or cancer [35].

The vast majority of studies supported the higher risk profile of non-attenders; however, non-attenders were found to have lower levels of cholesterol than those who did attend in a post-study follow up [32]. In another study initial responders had higher total cholesterol but lower diastolic blood pressure than those who had to be re-contacted [24].

In general, frequent or recent consulters at General Practice were found to be more likely to present for a health check $[23,32,36,40,41,44]$ but for some people this 
recent or on-going contact can be a reason not to attend $[27,42,51,57]$. Consequently, this inconsistent relationship between frequency of attendance at GP practice and the likelihood of participation in preventive health screening has been described as 'complex' [40], and the two areas are inherently related. Some studies have shown that frequent or recent GP consulters are more likely to attend for a health check [23,32,36,40,41,44]; for example, over $90 \%$ of patients who attended a health check at a shopping centre reported having a regular source of medical care [22]. Conversely, other patients cited recent or ongoing contact with their GP as reasons for not attending a health check $[27,42,51,57]$. A survey of attenders and nonattenders at General Practice in the past year showed that attenders were more likely to indicate that they would make an appointment for a health check compared to non-attenders $(83 \%$ v $66 \%)$ [58].

\section{Discussion}

This review identified a substantial number of primary empirical studies contributing data to questions of uptake. Although the heterogeneous nature of interventions and populations precluded formal statistical metaanalysis, there appeared sufficient commonality across studies to inform a number of key conclusions. Routine health check-ups appear to be taken up inequitably with gender, age, socio-demographic status and ethnicity all associated with differential service use. Furthermore, non-attenders appeared to have greater clinical need or risk factors suggesting that differential uptake may lead to sub-optimal health gain and contribute to inequalities via the inverse care law. Our findings provide an initial contribution to the development of programme theories or conceptual frameworks to underpin future strategies, as suggested by NICE and others $[59,60]$.

\section{Limitations of the review}

Established and appropriate search strings were not available thus necessitating the development of new strategies. Like all reviews we cannot guarantee that studies have not been missed. However, our emphasis was on sensitivity over specificity resulting in almost 18,000 papers being examined by members of the team. We therefore believe that it is likely that few papers were missed. The purpose of the review was to identify sufficient studies across diverse contexts to inform the theoretical and practical development of future interventions to improve uptake of health checks. This necessary focus on diversity also meant that formal statistical meta-analysis or metaregression of predictors of uptake would have been inappropriate.

The majority of studies came from North America $(n=13)$ and Europe $(n=24)$, and the remaining two papers were from Israel and Taiwan. There may have been benefits from loosening inclusion criteria to include both geriatric health checks and non-developed countries. Such diversity could potentially lead to sufficient numbers of papers with common interventions or populations as to justify a number of meta-analyses of effectiveness or meta-regression of predictors of uptake. While the scoping nature of this study precluded such an approach for pragmatic reasons we have demonstrated that such a review may be feasible and desirable in the future.

\section{The inverse care law in operation}

In his original description of the inverse care law Julian Tudor Hart's argued that "the availability of good medical care tends to vary inversely with the need for the population served" [14]. The validity of his law was demonstrated in a number of studies and in a number of ways in our review. Men from lower socio-economic backgrounds and on low incomes were consistently found to be less likely to engage with check-ups than women or people from a higher socio-economic status. Both of these variables are well established risk factors for a range of clinical conditions, perhaps most importantly in the context of this study, cardiovascular disease. This, again, was reinforced through this review since nonattenders were consistently found to have a range of poor lifestyle behaviours including smoking, alcohol consumption and diet. These findings suggest that without adaptation or increased efforts to increase uptake from these more "needy" populations there is the possibility that health checks, like other contemporary public health policies, risk exacerbating rather than narrowing health inequalities [61].

\section{Implications for future service design}

Given the diversity of populations, clinical needs and motives not to attend health checks, a "one size fits all" solution consisting of promoting attendance at health checks and subsequent support for behaviour change is simplistic and flawed, particularly in the interaction with patients with complex needs [62]. Indeed, the current focus on a limited number of delivery types, and a failure to tailor services may at least in part contribute to the problem. However, while it would appear sensible to assume that complex problems require complex solutions, there may be exceptions. The increasing role of both social marketing and financial incentives as drivers of behaviour change both focus on increasing perceived value while not essentially changing the service itself or addressing many of the pre-stated barriers. Incentive based schemes are gaining significant attention as a means of promoting behaviour change through extrinsic motivations [63-65]. However, such schemes have led to a number of questions with regard to political acceptability, ethical justification and effectiveness. In addition, 
questions over their ability to sustain behaviour modification, once an incentive is withdrawn, were raised [64]. Given the preponderance of people on lower incomes among non-attenders, incentive schemes, whether based on finance or benefits in kind, may prove particularly effective and could be considered.

If tailoring of health check-ups is to take place then consideration would need to be given to the varied demands that this would place on health professionals charged with delivering the service. Among the challenges surrounding service delivery are clinician's frequently low adherence to protocols on prevention within consultations [66-68]. This may be related to a lack of awareness of, and agreement with, guidelines, or a belief that many practices and outcomes would be difficult to change due to time pressure and other issues $[69,70]$.

Moreover, clinicians in deprived communities are faced with higher rates of ill health and multi-morbidities, poor patient access, and high stress levels among clinicians, which in turn lead to higher demands on the service and service provider [71]. Diversifying the provision of health checks to multiple tailored forms may well exacerbate these pressures and reduce service compliance to such new protocols unless tailoring is largely cost and time neutral. Certainly, increasing intervention complexity may be associated with reduced levels of implementation. An alternative approach may be to provide increased emphasis on opportunistic health checks at routine consultations; although even this has still been found to be time consuming [8]. However, it has recently been suggested from a substantive evaluation of a complex outreach prevention service that the complexity of reasons for nonengagement among some people may not be predictable or "read in advance" [59]; this would suggest that whatever tailoring to services is made there will always be an imperative on the skill of the clinician to judge and respond to unique opportunities within the opportunistic consultation as well as wider systems approaches [59].

\section{Conclusion}

All of these challenges and complexities indicate that a diverse range of approaches may be required if the full benefit of health checks are to be realised. While tailoring and targeting the form of delivery may have a role to play, it is likely that their implementation would require increased investment to ensure adoption and sustainability, particularly if narrowing health inequalities is a serious and central goal of such health checks. The Marmot report "Fairer Society Fairer Lives", recently argued for a policy of "proportionate universalism":

"Focusing solely on the most disadvantaged will not reduce health inequalities sufficiently. To reduce the steepness of the social gradient in health, actions must be universal, but with a scale and intensity that is proportionate to the level of disadvantage. We call this proportionate universalism." p15 [72].

Such proportionate universalism would define "tailoring" as much in terms of the scale and intensity of action required for those most in need, as much as any changes in objective intervention form. Whatever approach is adopted, it is important that a clear theoretical underpinning that acknowledges both the complexity of the diverse population needs/attitudes and the challenges currently facing primary care and associated public health services is required. This synthesis of current findings has attempted to make a contribution to such a development.

\section{Competing interests}

The authors declare that they have no competing interests.

\section{Authors' contributions}

$\mathrm{RD}$ designed the study, conducted the review and contributed to the writing of the paper. BW was involved in the design of the study and wrote the paper. CMC contributed to the review and the paper. MTH contributed to the review and the paper. All authors read and approved the final manuscript.

\section{Author details}

${ }^{1}$ Social Dimensions of Health Institute, 11 Airlie Place, University of Dundee, Dundee, UK. ${ }^{2}$ Nursing, Midwifery \& Allied Health Professions Research Unit, Iris Murdoch Building, University of Stirling, Stirling, UK. ${ }^{3}$ Division of Population Health Sciences, Ninewells Hospital \& Medical School, University of Dundee, Dundee, UK.

Received: 14 May 2012 Accepted: 24 August 2012

Published: 31 August 2012

\section{References}

1. Van den Dool C: Allgemeinmedizin. International 1973, 3:100

2. Riley JC: Rising life expectancy: A global history. Cambridge: Cambridge University Press; 2001.

3. Hanlon P, Walsh D, Buchanan D, Redpath A, Bain M, Brewster D, Chalmers J, Muir R, Smalls M, Willis J, et al: Chasing the Scottish effect: Why Scotland needs a step-change in health if it is to catch up with the rest of Europe. Glasgow: Public Health Institute of Scotland/Information and Statistics Division; 2001.

4. Scottish Executive Health Department: Building a health service fit for the future - A national framework for service change in the NHS in Scotland. Edinburgh: The Scottish Executive; 2005.

5. The Scottish Government: Better health, better care: Action plan. Edinburgh: The Scottish Government; 2007.

6. The Scottish Government: Equally well: Report of the ministerial task force on health inequalities. Edinburgh: The Scottish Government; 2008.

7. Delivering the NHS health check: A practical guide to implementation. http://www.healthcheck.nhs.uk/Library/F26E1C01d01.pdf.

8. Watt G, O'Donnell C, Sridharan S: Building on Julian Tudor Hart's example of anticipatory care. Primary Health Care Research and Development 2011, 12(1):3-10.

9. U.S. Preventive Services Task Force: Guide to clinical preventive services. Rockville: Agency for Healthcare Research and Quality; 2004.

10. National Institute for Health and Clinical Excellence: Prevention of cardiovascular disease (PH25). London: National Institute for Health and Clinical Excellence; 2010.

11. Over-40s health check provision in England 'patchy. http://www.bbc.co.uk/ news/health-16137013.

12. NHS health check national learning network 13th workshop. http://www. healthcheck.nhs.uk/Library/DHupdateonlyMarch2012v12.ppt.

13. Dalton ARH, Bottle RA, Okoro C, Majeed FA, Millett C: Uptake of the NHS health checks programme in a deprived, culturally diverse setting: cross sectional study. J Epidemiol Community Health 2011, 65:A21. 
14. Tudor Hart J: The inverse care law. Lancet 1971, 297(7696):405-412.

15. Medical Research Council: A framework for development and evaluation of RCTs for complex interventions to improve health. London: Medical Research Council; 2000.

16. Craig P, Dieppe P, Macintyre S, Michie S, Nazareth I, Petticrew M: Developing and evaluating complex interventions: the new medical research council guidance. BMJ 2008, 337:1655.

17. Arksey H, O'Malley L: Scoping studies: towards a methodological framework. International Journal of Social Research Methodology 2005, 8(1):19-32.

18. Richardson WS, Wilson MC, Nishikawa J, Hayward RS: The well-built clinical question: a key to evidence-based decisions. ACP J Club 1995, 123(3):A12-A13.

19. Popay J, Roberts H, Sowden A, Petticrew M, Arai L, Rodgers M, Britten N, Roen K, Duffy S: Guidance on the conduct of narrative synthesis in systematic reviews. A product from the esrc methods programme. Lancaster: Institute of Health Research: ESRC Methods Program; 2006.

20. Bletzer KV: Review of a health fair screening program in Mid-Michigan. J Community Health 1989, 14(3):149-157.

21. Culica D, Rohrer J, Ward M, Hilsenrath P, Pomrehn P: Medical checkups: who does not get them? Am J Public Health 2002, 92(1):88-91.

22. Greenland P, Hildreth NG, Maiman LA: Attendance patterns and characteristics of participants in public cholesterol screening. Am J Prev Med 1992, 8(3):159-164.

23. Waller D, Agass M, Mant D, Coulter A, Fuller A, Jones L: Health checks in general practice: another example of inverse care? BMJ 1990, 300(6732):1115-1118.

24. Jacobsen BK, Stensvold I, Fylkesnes K, Kristiansen IS, Thelle DS: The Nordland health study - design of the study, description of the population, attendance and questionnaire response. Scand J Soc Med 1992, 20(3):184-187

25. Simpson WM, Johnston M, McEwan SR: Screening for risk factors for cardiovascular disease: a psychological perspective. Scott Med J 1997, 42(6):178-181

26. Thomas KJ, Nicholl JP, Fall M, Lowy A, Williams BT: Case against targeting long term non-attenders in general practice for a health check. Br J Gen Pract 1993, 43(372):285-289.

27. Wall M, Teeland L: Non-participants in a preventive health examination for cardiovascular disease: characteristics, reasons for non-participation, and willingness to participate in the future. Scand J Prim Health Care 2004, 22(4):248-251.

28. Cherrington A, Corbie-Smith G, Pathman DE: Do adults who believe in periodic health examinations receive more clinical preventive services? Prev Med 2007, 45(4):282-289.

29. Karwalajtys T, Kaczorowski J, Chambers LW, Levitt C, Dolovich L, McDonough B, Patterson C, Williams JE: A randomized trial of mail vs. telephone invitation to a community-based cardiovascular health awareness program for older family practice patients [ISRCTN61739603]. BMC Fam Pract 2005, 6:35.

30. Hsu HY, Gallinagh R: The relationships between health beliefs and utilization of free health examinations in older people living in a community setting in Taiwan. J Adv Nurs 2001, 35(6):864-873.

31. Bowden RG: Comparisons of cholesterol screening participants and non-participants in a university setting. International Electronic Journal of Health Education 2001, 4:100-104.

32. Franks P, Gold MR, Bell BP, Naumburg EH, Engerman J: Barriers to cholesterol testing in a rural-community. J Fam Pract 1991, 32(6):614-618.

33. Jones A, Cronin PA, Bowen M: Comparison of risk factors for coronary heart disease among attenders and non-attenders at a screening programme. Br J Gen Pract 1993, 43(374):375-377.

34. Sonne-Holm S, Sorensen TIA, Jensen G, Schnohr P: Influence of fatness, intelligence, education and sociodemographic factors on response rate in a health survey. J Epidemiol Community Health 1989, 43(4):369-374.

35. Walker M, Shaper AG, Cook DG: Non-participation and mortality in a prospective study of cardiovascular disease. J Epidemiol Community Health 1987, 41(4):295-299.

36. Thorogood M, Coulter A, Jones L, Yudkin P, Muir J, Mant D: Factors affecting response to an invitation to attend for a health check. Journal of Epidemioogy and Community Health 1993, 47(3):224-228.

37. Dignan MB, Young LD, Crouse JR, King JM: Factors associated with participation in a preventive cardiology service by patients with coronary heart disease. South Med J 1995, 88(10):1057-1061.
38. Griffiths $C$, Cooke $S$, Toon P: Registration health checks: inverse care in the inner city? Br J Gen Pract 1994, 44(382):201-204.

39. Wilson S, Sisk RJ, Baldwin KA: Health beliefs of blue collar workers: increasing self efficacy and removing barriers. AAOHN J 1997, 45(5):254-257.

40. Boshuizen HC, Viet AL, Picavet HSJ, Botterweck A, Van Loon AJM: Non-response in a survey of cardiovascular risk factors in the Dutch population: determinants and resulting biases. Public Health 2006 120(4):297-308

41. Pill R, French J, Harding K, Stott N: Invitation to attend a health check in a general practice setting: comparison of attenders and non-attenders. J R Coll Gen Pract 1988, 38(307):53-56.

42. Persson $L G$, Lindstrom $K$, Lingfors $H$, Bengtsson $C$ : A study of men aged 33-42 in Habo, Sweden with special reference to cardiovascular riskfactors. Scand J Soc Med 1994, 22(4):264-272.

43. Christensen B: Characteristics of attenders and non-attenders at health examinations for ischaemic heart disease in general practice. Scand $J$ Prim Health Care 1995, 13(1):26-31.

44. Difford F, Telling JP, Davies KR: Continuous opportunistic and systematic screening for hypertension with computer help: analysis of nonresponders. BMJ 1987, 294(6580):1130-1132

45. Engebretson J, Mahoney JS, Walker G: Participation in community health screenings: a qualitative evaluation. J Community Health Nurs 2005 22(2):77-92.

46. Harpole LH, McBride C, Strigo TS, Lobach D: Feasibility of a tailored intervention to improve preventive care use in women. Preventive Medicine: An International Journal Devoted to Practice and Theory 2000, 31(4):440-446

47. Norman P, Fitter M: Predicting attendance at health screening: organizational factors and patients' health beliefs. Counselling Psychology Quarterly 1991, 4(2-3):143-155.

48. Shiloh S, Vinter M, Barak Z: Correlates of health screening utilization: the roles of health beliefs and self-regulation motivation. Psychol Health 1997, 12(3):301-317.

49. Norman $\mathrm{P}$, Conner M: The role of social cognition models in predicting attendance at health checks. Psychol Health 1993, 8(6):447-462.

50. Norman P, Fitter M: Patients' views on health screening in general practice. Fam Pract 1991, 8(2):129-132.

51. Nielsen KDB, Dyhr L, Lauritzen T, Malterud K: "You can't prevent everything anyway": a qualitative study of beliefs and attitudes about refusing health screening in general practice. Fam Pract 2004, 21(1):28-32.

52. Norman P, Fitter M: Intention to attend a health screening appointment: some implications for general practice. Counselling Psychology Quarterly 1989, 2(3):261-272.

53. Williams A, Mason A, Wold J: Cultural sensitivity and day care workers: examination of a worksite based cardiovascular disease prevention project. AAOHN J 2001, 49(1):35-43.

54. Ornstein SM, Musham C, Reid A, Jenkins RG, Zemp LD, Garr DR: Barriers to adherence to preventive services reminder letters: the patient's perspective. J Fam Pract 1993, 36(2):195-200.

55. Pill R, Stott $N$ : Invitation to attend a health check in a general practice setting: the views of a cohort of non-attenders. J R Coll Gen Pract 1988, 38(307):57-60

56. Thompson NF: Inviting infrequent attenders to attend for a health check: costs and benefits. Br J Gen Pract 1990, 40(330):16-18.

57. Hegarty $V$, Donovan MC, Pye M, Khaw KT: Reasons for nonresponse among older adults. J Am Geriatr Soc 1995, 43(9):1066-1067.

58. Levine JA: Are patients in favour of general health screening? J R Soc Med 1991, 84(5):280-283

59. Mackenzie M, Turner F, Platt S, Reid M, Wang Y, Clark J, Sridharan S, O'Donnell CA: What is the 'problem' that outreach work seeks to address and how might it be tackled? Seeking theory in a primary health prevention programme. BMC Health Serv Res 2011, 11(350).

60. Pawson R: Evidence based policy: the promise of 'realist synthesis'. Evaluation 2002, 8(3):340-358.

61. Watt G: The inverse care law today. Lancet 2002, 9328:252-254

62. Watt G: Anticipatory care in very deprived areas. Br J Gen Pract 2011, 61(584):228

63. Marteau TM, Ashcroft RE: Using financial incentives to achieve healthy behaviour. BMJ 2009, 338:983-985.

64. Wilkinson E: Can you pay people to be healthy? Lancet 2008 371(9621):1325-1326. 
65. Wilkinson RG, Pickett KE: The spirit level: why more equal societies almost always do better. London: Penguin; 2009.

66. Backer EL, Geske JA, MCllvain HE, Dodendorf DM, Minier WC: Improving female preventive health care delivery through practice change: an every woman matters study. J Am Board Fam Med 2005, 18:401-108.

67. Hunt WA, Matarazzo JD, Weiss SM, Gentry WD: Associative learning, habit, and health behavior. Journal Of Behavioral Medicine 1979, 2(2):111-124.

68. Dubey V, Mathew R, Iglar K, Moineddin R, Glazier R: Improving preventive service delivery at adult complete health check-ups: the preventive health evidence-based recommendation form (PERFORM) cluster randomized controlled trial. BMC Fam Pract 2006, 7(44).

69. Hudon E, Beaulieu MD, Roberge D: Integration of the recommendations of the Canadian task force on preventive health care. Fam Pract 2004, 21:11-17.

70. Yarnall KS, Pollak Kl, Ostbye T, Krause KM, Michener JL: Primary care: is there enough time for prevention? Am J Public Health 2003, 93(4):635-641.

71. Mercer SW, Watt GC: The inverse care law: clinical primary care encounters in deprived and affluent areas of Scotland. Ann Fam Med 2007, 5(6):503-510

72. Marmot M, Allen J, Goldblatt P, Boyce T, McNeish D, Grady M, Geddes I: Fair society, Healthy Lives: Strategic Review of Health Inequalities in England post-2010. London: The Marmot Review; 2010.

doi:10.1186/1471-2458-12-723

Cite this article as: Dryden et al:: What do we know about who does and does not attend general health checks? Findings from a narrative scoping review. BMC Public Health 2012 12:723.

\section{Submit your next manuscript to BioMed Central and take full advantage of:}

- Convenient online submission

- Thorough peer review

- No space constraints or color figure charges

- Immediate publication on acceptance

- Inclusion in PubMed, CAS, Scopus and Google Scholar

- Research which is freely available for redistribution 